\title{
Wall Paintings in Ancient Cyprus The Hellenistic and Roman Tombs of Paphos and Its Region
}

\section{VASiliki Lysandrou, Demetrios Michaelides}

\begin{abstract}
This paper presents the wall paintings decorating a number of Hellenistic and Roman tombs, of various architectural types, in Paphos and the region. The paper gathers together for the first time all the known published and unpublished painted tombs of the city, which are studied on the basis of observations made on the actual decoration preserved either in situ or in the laboratory of the Paphos District Museum, and with the use of all pertinent publications. A catalogue of these tombs has been created and this is accompanied by a map with the geographic location of each example. The various themes represented on wall paintings have been divided into groups and are discussed accordingly, while the manufacturing technology of a sample of the wall paintings is examined using both non-contact and analytical tools.
\end{abstract}

Keywords: Hellenistic period, Roman period, wall paintings, tombs, Nea Paphos, Cyprus

Vasiliki Lysandrou, Cyprus University of Technology, Limassol; vasiliki.lysandrou@cut.ac.cy;

(D) 0000-0002-1448-7599

Demetrios Michaelides, University of Cyprus, Nicosia; d.michaelides@ucy.ac.cy; (1) 0000-0002-5320-7617

Only a very small number of Hellenistic and Roman tombs from Cyprus had any sort of decoration. This consisted mainly of wall paintings, architectural mouldings, either plain or plaster-coated and painted, and stucco imitation of architecture. ${ }^{1}$ Tomb decoration employing luxurious and prised materials such as coloured marbles and stones are hitherto not attested on Cyprus. Also, unknown to date are mosaics decorating the interior of a tomb. Although two pebble mosaics seemingly belonging to heroa situated above rock-cut burial chambers are recorded, neither was found in a necropolis. ${ }^{2}$

\footnotetext{
${ }^{1}$ For a first assessment of the surviving evidence of wall paintings, see: Michaelides 2004. See also: Raptou 2007. For an inclusive study on all types of decoration found in Hellenistic and Roman tombs in Cyprus, see: Lysandrou 2014: 267-306. For pre-Hellenistic examples of tomb painting (e.g. Tomb 80 of Salamis), see: Michaelides 2004: 89-90, Fig. 1; Guimier-Sorbets, Michaelides 2009: 216-218, Figs 21.1-4.

${ }^{2}$ One is on the Acropolis of Kourion (Rupp 1978; 1982; Guimier-Sorbets 2009: 145-147), the other on the Fabrika hill in Nea Paphos (Hadjisavvas 1998: 33-34; for its possible association with a heroon, see:
} 
None of the known Hellenistic and Roman tombs of Cyprus preserve complete painted decoration and the only certain cases where the evidence shows that the entire tomb, walls, and ceiling ${ }^{3}$ were thus decorated are the Hellenistic tombs T.1 and T.3 (see Table $\mathbf{1}$ below). The Roman T.23 is a likely candidate, but its roof was quarried away and it is impossible to know if it was decorated. Several other tombs may have been once painted all over, but what survives is far too fragmentary to allow a decision one way or the other. What is certain, however, is that in several tombs only parts of the interior, such as an arcosolium and the area around it, as in T.24, was painted. Other tombs were simply whitewashed. ${ }^{4}$

This paper starts with a presentation of the Hellenistic and Roman painted tombs of Paphos that were investigated during the 2010 survey. ${ }^{5}$ It then briefly discusses the architecture of the painted tombs, and the themes encountered are grouped and briefly analysed. The paper concludes with remarks related to the colours used in the wall paintings and the manufacturing techniques, based on observations and analytical methods carried out in 2010-2011.

\section{HELLENISTIC AND ROMAN PAINTED TOMBS}

Wall paintings are an important element and an integral part of Hellenistic and Roman tomb architecture, primarily due to their reciprocal relations that define and determine each other. They are also important in terms of the symbolism of their representations, and as a general window into the materiality, technology, implementation, and knowhow of the time of their creation. Only a very small percentage of the hundreds of Hellenistic and Roman tombs known all over Cyprus ${ }^{6}$ were decorated with wall paintings, and these are almost exclusively restricted to the Paphos region. This rarity of the wall paintings can be related to the fact that most of the tombs were looted in the past and reused as animal shelters, dwellings, medieval workshops, rubbish pits, and so

Guimier-Sorbets 2009: 147-152). Of the multitude of Roman mosaic pavements of Cyprus, only one has been found within the site of a necropolis: a fragmentary floor mosaic discovered in the western necropolis of Paphos, on top of a grave-type tomb containing an Attic sarcophagus, is datable to the fourth-fifth century AD, and is apparently not directly related to the tomb, although this might be the case of a prolonged worship at the burial place of a particular individual (Michaelides 2005: 399-401; Raptou 2009). For even later mosaics directly associated with burials, see: Michaelides 2014: 8-11 (with earlier bibliography). For a few examples of sculptural and other decoration, see: Lysandrou 2014: 297-306.

${ }^{3}$ For the painted ceilings of Hellenistic and Roman tombs, see: Michaelides 2004.

${ }^{4}$ Only two examples of tombs where the floor was painted are reported: T.23 (Michaelides 2004: 93) and T.17 (Raptou 2007: 118).

${ }^{5}$ The article is based on observations made during the 2010 survey of the tombs given in Table 1, as well as on published material. The in situ investigation was carried out by the first author in the framework of her PhD dissertation (Lysandrou 2014); bibliographic references were cross-checked, while fragments of wall painting decoration were also sought and examined in the laboratory and Paphos District Museum. Wall paintings in tombs excavated since are taken into consideration only if they have been published or even simply mentioned in the literature.

${ }^{6}$ For the indexing of Hellenistic and Roman tombs in Cyprus, see: Lysandrou 2014: 23-153. 
on, ${ }^{7}$ which resulted in the complete loss of their decoration. Furthermore, the climatic conditions on the island do not favour the preservation of ancient wall paintings.

All known Hellenistic and Roman period tombs decorated with wall paintings are located in Nea Paphos ${ }^{8}$ and its region. ${ }^{9}$ The city, as the administrative, political, and religious centre of the island during the Ptolemaic and Roman period, was undoubtedly ahead of other centres and exhibited special characteristics with regard to funerary architecture and decoration, as for example in the use of wall paintings. Given that this type of decoration is found only in large tombs, most with elaborate architecture, it is evident that wall paintings in a funerary context were the privilege of an elite class - economically robust families of the time, resident in Paphos. This is reflected in the tomb architecture, which also presents notable samples in Paphos in comparison to other areas of the island. ${ }^{10}$

Table 1 presents all Hellenistic and Roman painted tombs of Nea Paphos that were visited during the 2010 survey. Specifically, it includes tombs that preserve part of their wall paintings, and, in the case of tombs that were not accessible, also fragments of their decoration kept in the Paphos District Museum. The table lists also other Hellenistic and Roman tombs with painted decoration that were not examined during the 2010 survey or that have been published since that date. These entries are highlighted in pale grey. They are considered and referenced in this article but are excluded from the remarks on the manufacturing technology, preparation technique and colour analysis. Some of the specimens considered present only fragments with a single colour, an indication, all the same, that the tomb was painted. The serial number in the first column of the table was given by the authors and will be used throughout the article. For each tomb, all bibliographic references are provided in the form of footnotes. ${ }^{11}$ The official registration number of the Department of Antiquities of Cyprus is given in the second column, while the third column provides the location of the tomb. All tombs listed in Table $\mathbf{1}$ are geographically located on Fig. 1 (starting from the westernmost tomb and moving clockwise).

${ }^{7}$ For instance, T.1 at the locality Ammoi, the wall paintings of which do survive, was used as a stable (Michaelides 2004: 90), as was T.21 (Raptou 2006: 317-319). For the alteration of a tomb into a workshop in medieval times, see the relevant remarks in: Papageorghiou (Ed.) 1991: 69.

8 These are included in Table 1.

${ }^{9}$ In the region of Paphos the following examples are documented (but not included in Table 1): fragments of wall painting are reported in a rock-cut tomb at Ayios Georgios in Peyeia, depicting a tabula ansata (Anastasiadou 2000: 336). However, no traces are visible in the accessible tombs of the necropolis (Loulloupis (Ed.) 1992: 67). Remnants of wall paintings are preserved in a tomb at the locality Ellenospelioi near the village of Anavargos, 3.5km north-east of Paphos. These, however, consisting mainly of simple red crosses, were certainly painted later, in order to 'Christianise' the tombs. On the phenomenon, see: Papageorghiou, Foulias 2013: 205-208; Michaelides 2001: 181. Also, remnants of wall painting are visible on the entrance of a loculus opposite the dromos at Ellenospelioi-Anavargos, evoking a door closing the loculus (Lysandrou 2014: 275).

${ }^{10}$ For the very individual funerary architecture of Nea Paphos, see: Guimier-Sorbets, Michaelides 2009; Lysandrou 2014; Michaelides, Guimier-Sorbets 2016.

11 All publications regarding each tomb pertinent to its archaeological/art historical aspect (i.e. detection, excavation, architecture, themes represented), are scrupulously given here. For bibliography on the archaeometric examination of the paintings, see infra. 
Table 1. Tombs with wall paintings in Paphos; tombs highlighted in pale grey were not examined during the 2010 survey or have been published after this date

\begin{tabular}{|c|c|c|}
\hline Serial no. & Registration no. & Location / locality \\
\hline T.1 & Tomb $1^{12}$ & Ammoi \\
\hline T.2 & Tomb $1^{13}$ & as above \\
\hline T.3 & Tomb $2^{14}$ & as above \\
\hline T.4 & P.M. $2463^{15}$ & Tombs of the Kings Avenue near Glyky nero \\
\hline T.5 & P.M. $3067^{16}$ & Glyky Nero \\
\hline T.6 & ${\text { without no. }{ }^{17}}^{18}$ & Antinavarchou Eleftheriou Chandrinou Street \\
\hline T.7 & without no. $^{18}$ & Georgiou Seferi Street \\
\hline T.8 & P.M. $3614^{19}$ & Adamantiou Korae Street / Ayios Theodoros \\
\hline T.9 & P.M. $3330^{20}$ & Tombs of the Kings Avenue \\
\hline T.10 & P.M. $3510^{21}$ & 'Tombs of the Kings' necropolis \\
\hline T.11 & Tomb $2^{22}$ & as above \\
\hline T.12 & Tomb immediately north of Tomb $3^{23}$ & as above \\
\hline T.13 & Tomb $4^{24}$ & \\
\hline
\end{tabular}

${ }^{12}$ Tombs T.1 and T.3 from Ammoi were found looted and were used as stables until Kyriacos Nicolaou cleared them for the Department of Antiquities in 1965 (Nicolaou 1966b: 600, Figs 27-28). Given the state they were found in, the few finds were not published. The discovery, style and iconography of the wall paintings, however, have been discussed in several publications, including: Nicolaou 1966a: 41; Karageorghis 1966: 384-385; Karageorghis (Ed.) 1975: Figs 37-38; Karageorghis 1975: 851, Fig. 75; Nicolaou 1976: 64-65; Karageorghis 1976: 895-896; Młynarczyk 1990: 237-238; Michaelides 1995: Fig. on p. 108; Hadjisavvas 1998: 28; Alabe 2002: 239, Fig. 7; Michaelides 2004: 90-92, Figs 2-3; and in more detail in: Guimier-Sorbets, Michaelides 2009: 226-229, Figs 21.35-38, 42-43. See also: Michaelides et al. forthcoming, and Hadjistephanou 2016: 376-380, Figs 4-10, with Figs 5-9 being more illustrations of Tomb 2 (wrongly labelled as Tomb A).

${ }^{13}$ Roman built tomb added in front of the entrance to the Hellenistic chamber tomb (T.1).

${ }^{14}$ As in footnote 12, above.

${ }^{15}$ Hadjisavvas 1982; Karageorghis (Ed.) 1982: 20, 42-43; Karageorghis 1982: 708-709; Michaelides 2004: 93, Fig. 6. See also: Hadjistephanou 2016: 380, Figs 11-14 on the restoration of the tomb and the conservation of the wall paintings. For a detailed analysis of the painted decoration, see: Michaelides et al. forthcoming.

${ }_{16}$ Papageorghiou (Ed.) 1990: 68; Papageorghiou 1990: 951.

${ }^{17}$ Karageorghis (Ed.) 1980: 34-35; Karageorghis 1980: 794, Fig. 89; Michaelides 2004: 92-93.

${ }^{18}$ Raptou 2007: 121-124, Pls Vb, VIa.

${ }_{19}$ Raptou 2006: 320, n. 5; 2007: 124, Pl. VIb.

${ }^{20}$ This tomb is unpublished. Remains of its well-preserved wall paintings are kept in the Paphos District Museum. Some sections have been left in situ. The tomb is presently being studied for publication by Demetrios Michaelides and Vasiliki Lysandrou.

${ }^{21}$ Hadjisavvas, Flourentzos (Eds) 2007: 78-79; Raptou 2004: 311-321, Pls 40.1, 45.1; Michaelides 2004: 94-95, Figs 13-14; Raptou 2007: 120-121, Pls IVd, Va. See also: Hadjistephanou 2016: 384-385, Figs 23-26; Nicolaou 2004: 268-269.

${ }^{22}$ Hadjisavvas 2012: 19-20.

${ }^{23}$ The two tombs communicate through an opening, presumably made by tomb robbers. Hadjisavvas 2012: 38.

${ }^{24}$ Michaelides 2004: 92, Fig. 4. Quarried away save for a side wall with engaged cippi painted in white with red highlights. 


\begin{tabular}{|c|c|c|}
\hline Serial no. & Registration no. & Location / locality \\
\hline T.14 & Tomb $8^{25}$ & as above \\
\hline T.15 & Tomb $6^{26}$ & as above \\
\hline T.16 & P.M. $3734^{27}$ & next to the Municipal Art Gallery \\
\hline T.17 & P.M. $3591^{28}$ & Costi Palama Square / Ktima \\
\hline T.18 & ${\text { without no. }{ }^{29}}^{30}$ Loizidou Street / Exo Vrysi \\
\hline T.19 & P.M. $3882^{30}$ & Cristodoulou Sozou \& Sotiraki Markide \\
& Avenue / Skali \\
\hline T.20 & P.M. $2792^{31}$ & Trikalon Street \\
\hline T.21 & P.M. $3535^{32}$ & Ikarou Street \\
\hline T.22 & P.M. $2892^{33}$ & Diagorou Street \\
\hline T.23 & P.M. $2902^{34}$ & as above \\
\hline T.24 & P.M. $2779^{35}$ & Iasonos Street \\
\hline T.25 & P.M. $2606^{36}$ & Kato Paphos, Eastern necropolis \\
\hline T.26 & P.M. $3005^{37}$ & Poseidonos Avenue \\
\hline T.27 & P.M. $3022^{38}$ & as above \\
\hline
\end{tabular}

${ }_{25}$ Hadjisavvas 1988: 237-238; 1998: 13-65; Michaelides 2004: 92; Hadjisavvas 2012: 34-35; Mavrojannis 2016. For a response to the above, see: Hadjisavvas forthcoming.

${ }^{26}$ Hadjisavva 1982: 13-15; Karageorghis (Ed.) 1984: 37-38; Karageorghis 1984: 948-949; Hadjisavvas 1985: 264, 266, 268; Karageorghis (Ed.) 1985: 42-43; Karageorghis 1985: 944-945; Hadjisavvas 1998: 30-31; Michaelides 2004: 92; Guimier-Sorbets, Michaelides 2009: 219, 226, Figs 21-23; Hadjisavvas 2012: 30-31, Fig. 28.

27 Raptou 2013. The tomb was inaccessible during the 2010 survey, but fragments of its painted decoration kept in the Paphos District Museum were examined during the colour recording.

${ }^{28}$ Michaelides 2004: 94, Fig. 12; Raptou 2007: 118-120, Pl. IVb-c.

${ }^{29}$ Unpublished. Known as 'Megaw's tomb'.

${ }^{30}$ Radpour, Fischer, Kakoulli 2019: 7-8, Figs 6c, 7c-e.

${ }^{31}$ Karageorghis (Ed.) 1986: 57-59; Karageorghis 1986: 872-874; Nicolaou 1986: 193; Guimier-Sorbets, Michaelides 2009: 226, Fig. 21.32.

32 Raptou 2006: 317-330; Wood Conroy 2006: 331-342; Raptou 2007: 124-125, Pls VIc, VIIa-b; Hadjisavvas, Flourentzos (Eds) 2007: 79-80.

${ }^{33}$ Karageorghis 1987: 725-728; Michaelides 2004: 93, Fig. 7. See also: Nikolaou 1987: 180, Pl. LVI:15; Hadjistephanou 2016: 383, Figs 21-22.

${ }^{34}$ Karageorghis 1987: 725-728; Michaelides 2004: 93-94, Figs 8-9.

${ }^{35}$ Karageorghis (Ed.) 1986: 57-59; Karageorghis 1986: 872-874; Michaelides 2004: 93; Di Vita 1986-1987: 530, Figs 132-135.

${ }^{36}$ The tomb has been destroyed. It was excavated and recorded by Demetrios Michaelides in 1984.

${ }^{37}$ Karageorghis (Ed.) 1989: 58, 60; Karageorghis 1989: 842; Michaelides 2004: 94, Fig. 10. For the treatment and more photographs of the wall paintings, see: Hadjistephanou 2016: 380-382, Figs 15-18.

${ }^{38}$ Karageorghis (Ed.) 1989: 58; Karageorghis 1989: 842; Michaelides 2004: 94, Fig. 11. The tomb was broken into by a mechanical excavator during the expansion of a hotel in 1988. Michaelides began its excavation for the Department of Antiquities, but work had to be abandoned given the adverse conditions and the precarious state of the wall paintings on the collapsed dome and the loose masonry blocks. The wall paintings that were still in situ were consolidated, while the loose fragments were collected and are now kept in the wall painting conservation laboratory of the Department of Antiquities in Paphos. The tomb has been incorporated and is accessible in the gardens of the hotel and is awaiting further investigation. For the conservation, see: Hadjistephanou 2016: 382, Figs 19-21. 


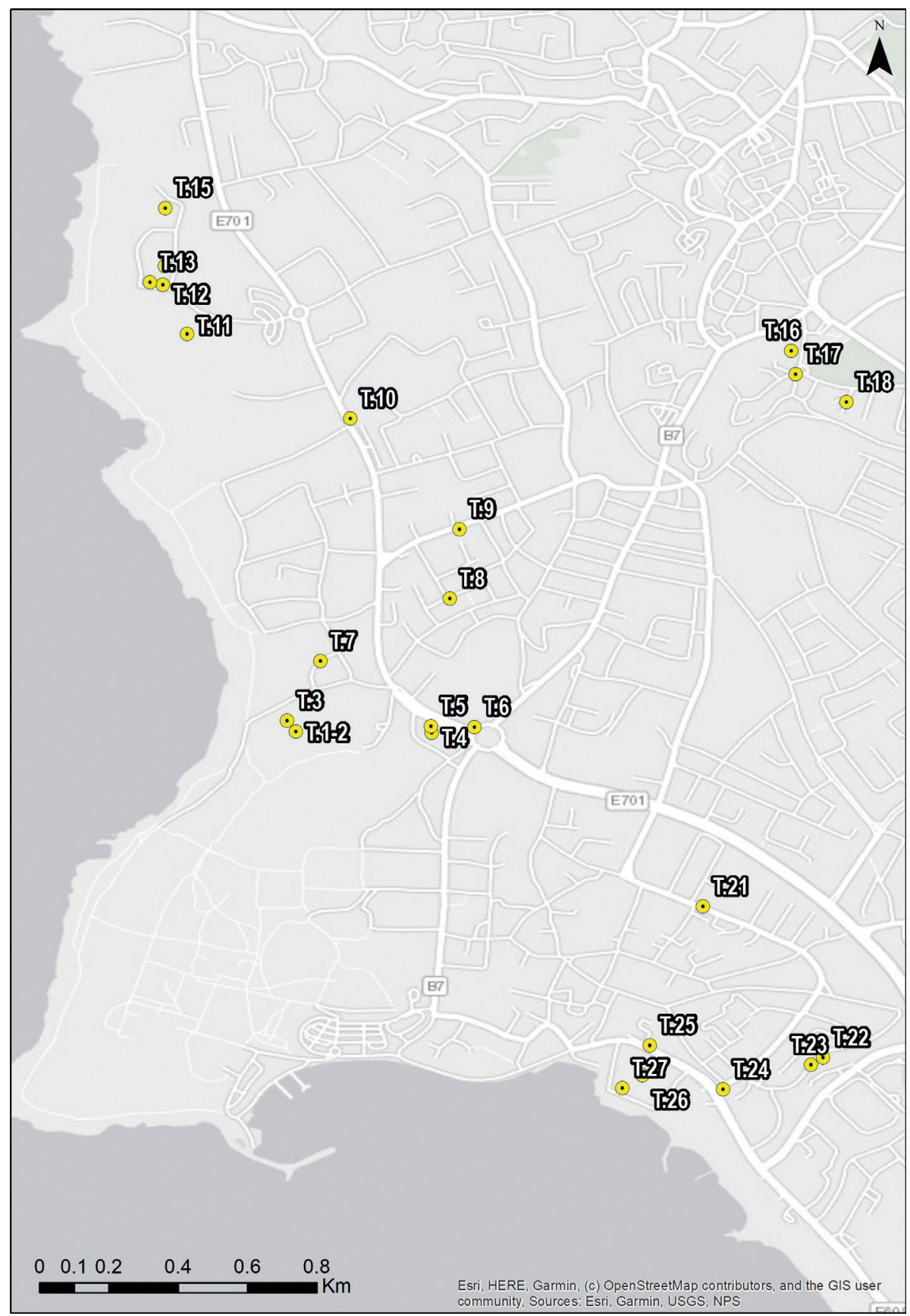

1. Map of Nea Paphos with the location of the painted tombs listed in Table 1 (processing: V. Lysandrou; base map source: ArcGIS). 


\section{THE ARCHITECTURE OF THE TOMBS WITH PAINTED DECORATION}

Most of the known tombs with painted decoration date to the Roman period. The Hellenistic examples are few, ${ }^{39}$ and some of them were reused, altered, and repainted in Roman times ${ }^{40}$

The Roman tombs that were decorated with wall paintings are primarily of built (i.e. T.4, T.7, T.21) or hybrid (partly hewn, partly built, i.e. T.27) types and they are rarely entirely hewn out of the natural bedrock as in atrium-type tombs or in tombs with loculi, which usually are of a Hellenistic date. ${ }^{41}$ They are equipped with arcosolia, which were especially favoured in the Paphos region during the Roman period, where the type attained perfection in the absolute geometry of its proportions and the execution of its individual features.

Wall paintings are only found in tombs with particularly elaborate architecture, regardless of the architectural type they belong to or whether these are rock-cut or built. This is a clear indication that painted decoration was the privilege of the economically robust families.

\section{THE THEMES REPRESENTED}

The themes found in the Hellenistic and Roman tomb paintings of Cyprus, are summarised in Table 2, together with a list of tombs in which particular motifs are attested; only the tombs that represent decorative motives are included in the table. A concise description of each theme is given below.

\section{GEOMETRIC DECORATION}

This category includes narrow and wide fillets, as well as a variety of other geometric motifs: the meander (T.3), the bead-and-reel, the egg-and-dart (T.3, T.7, T.17), the guilloche, the wave scroll (T.23), the so-called Macedonian-type star (T.1), the reticulate pattern (T.23), the diagonal crossbars (T.20), and other unidentified, seemingly geometric patterns. These are either used as frames or form part of the main composition.

\section{ARCHITECTURAL DECORATION}

Given that tombs were intended to evoke a domestic environment, as is the case with the atrium tombs at the 'Tombs of the Kings', ${ }^{42}$ as one would expect, painted imitation of architecture is very common. Other factors that may have contributed to the popularity

39 These include tombs T.1 and T.3, the loose fragments from T.20, as well as sparse remains in tombs T.11-T.15.

40 A Roman tomb complex (T.2) was added to the front of the Hellenistic T.1 at Ammoi, while T.3 was architecturally altered and exhibits at least two different layers of wall painting (Michaelides 2004: 91).

${ }^{41}$ Examples of these are T.11-T.15 in the necropolis of the 'Tombs of the Kings', as well as T.8, T.17 and T.20.

${ }^{42}$ For a discussion of the meaning and symbolism of the decoration of Macedonian tombs, see: Miller 1993: 17-20. 
Table 2. Themes encountered in the painted decoration of the Hellenistic and Roman tombs listed in Table 1

\begin{tabular}{|c|c|c|c|c|c|c|c|c|c|c|}
\hline \multirow[b]{3}{*}{$\begin{array}{c}\text { Tomb } \\
\text { serial } \\
\text { no. }\end{array}$} & \multicolumn{10}{|c|}{ Decoration theme } \\
\hline & \multirow[b]{2}{*}{ 苞 } & \multicolumn{4}{|c|}{ Architectural } & \multirow[b]{2}{*}{$\frac{\stackrel{\mathscr{U}}{\frac{U}{2}}}{0}$} & \multirow[b]{2}{*}{ 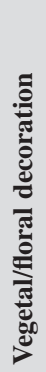 } & \multirow[b]{2}{*}{ 䒿 } & \multirow[b]{2}{*}{ 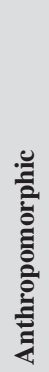 } & \multirow[b]{2}{*}{ } \\
\hline & & 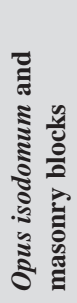 & 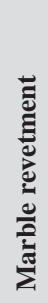 & 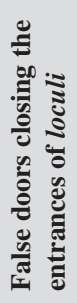 & 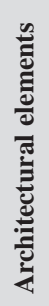 & & & & & \\
\hline T.1 & + & & + & & & + & + & + & & \\
\hline T.3 & + & & & & + & & + & & & \\
\hline T.4 & + & & + & & & + & + & + & & \\
\hline T.5 & & & & & & & & & & \\
\hline T.6 & + & & & & & & + & + & & \\
\hline T.7 & + & & & & & + & + & + & & \\
\hline Т.8 & & & + & & & + & + & & & + \\
\hline T.9 & & & & & & & & + & + & + \\
\hline T.10 & & & & & & + & + & & + & + \\
\hline T.11 & & & & & & + & & & & + \\
\hline T.12 & & & & + & & & & & & \\
\hline Т.14 & & & & & & + & & & & \\
\hline Т.15 & & & + & + & & & & & & \\
\hline Т.16 & & & & & & + & + & & + & \\
\hline Т.17 & + & + & & + & + & + & + & & + & \\
\hline T.19 & + & & + & & & & + & & & \\
\hline Т.20 & + & & & + & & & & & & \\
\hline Т.21 & + & & + & & & + & + & + & & \\
\hline Т.22 & & & + & & & + & + & & & + \\
\hline Т.23 & + & + & + & & & & + & & & \\
\hline Т.24 & & & & & & + & + & & & \\
\hline Т.25 & & & & & & & & & & + \\
\hline Т.26 & + & & + & & & + & + & + & & \\
\hline Т.27 & & & + & & & & + & & + & \\
\hline
\end{tabular}


of this category of decoration is the quick and economical means of reproducing precious materials, such as marble.

The types of imitated architecture and architectural elements can be divided into: opus isodomum and masonry blocks, marble revetment, false doors closing the entrances of loculi, and architectural elements.

\section{OPUS ISODOMUM AND MASONRY BLOCKS}

The imitation of opus isodomum is found in rock-cut chamber tombs, applied on the vertical walls of the burial chambers. It is usually rendered through painted imitation of rectangular stone blocks of white or off-white colour, delimited on their four sides by a double strip of black and red colour (T.17). A similar kind of imitation creates the impression of a built intrados in the arcosolia of rock-cut tombs (T.23; Fig. 2a), but also - rather surprisingly - in built tombs where the intrados are constructed with real masonry (T.21).

\section{MARBLE REVETMENT}

This is one of the commonest types of imitation of architectural decoration. Imitation of marble panels line the vertical walls of dromoi leading to the tomb entrance (i.e. T.22; Fig. 2b), the walls of burial chambers (T.1 and probably the lower part of a wall in T.15 $5^{43}$ and T.26), the tympana of arcosolia above the sarcophagi (i.e. T.4, ${ }^{44}$ T.8) or the pilasters 'supporting' the arched niche of the central arcosolium of T.21. ${ }^{45}$ Imitations of marble panels are also found in the intrados of an arcosolium in tomb T.8 in rhomboid panels instead of the more usual rectangular ones, as well as in T.19. The slabs closing a sarcophagus in one of the arcosolia of T.23 are painted with a schematic representation of marble.

In these Roman examples, the main volume of the marble slab is usually depicted in off-white or yellow ochre and is framed by black and red stripes. The type can sometimes be identified as giallo antico, cipolllino and alabaster (e.g. in T.8, T.21), but on the whole such veneering is rendered in a schematic and simplified way, with superimposed zigzag lines in ochre or light grey-green (a good example of this is found in T.22). This is in complete contrast to what we see in the Hellenistic tomb T.1, the earliest, best preserved, and most extensive painted imitation of architectural elements in Cyprus. Walls and ceiling of the antechamber of this tomb are entirely covered with wall paintings. On all four walls the painted imitation consists of large realistically rendered alabaster panels sitting on a dark-coloured plinth and topped by a band of smaller rectangular slabs or blocks of red colour, probably imitating a rosso antico type of stone, each outlined in white.

\footnotetext{
${ }^{43}$ In the NE area of the atrium. Not visible today.

44 This specific motif could be imitating isodomic masonry construction instead of marble revetment.

45 Wood Conroy 2006: 335, Fig. 8.
} 

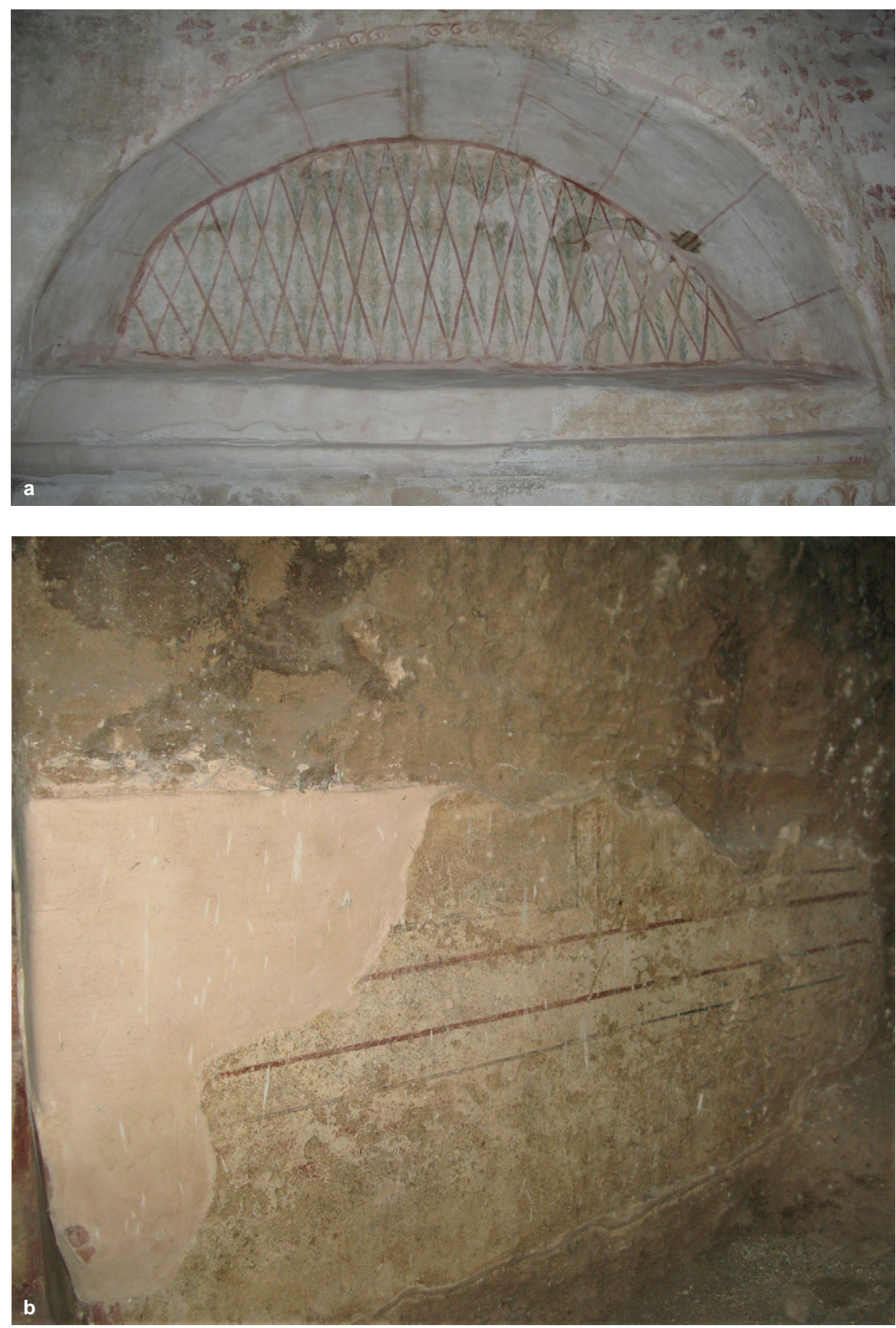

2a. Imitation of a built intrados in the arcosolia of rock-cut T.23; b. imitation of marble panels on the wall of the dromos leading to the entrance of T.22 (Phot. V. Lysandrou). 


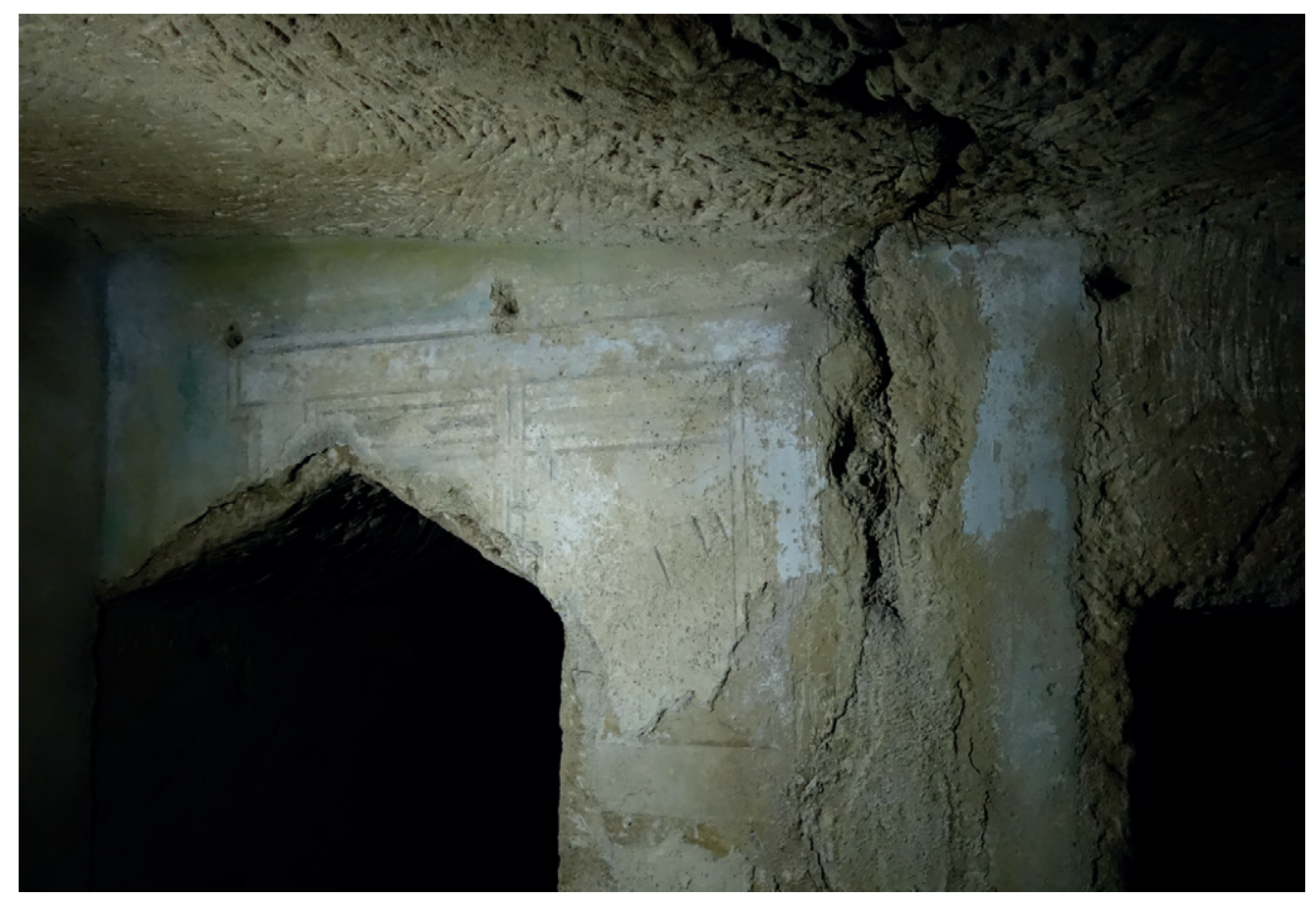

3. Painted false door closing the entrance of a loculus in T.18 (Phot. D. Michaelides, archive 1983).

\section{FALSE DOORS CLOSING THE ENTRANCES OF LOCULI}

The doors were usually painted to cover a larger area than the actual opening of the burial loculus, or they were not in line with its real opening presumably in order to distract tomb robbers or any kind of disturbance to the burial. In some cases, these false doors covered a much larger area than what was actually necessary (T.18; Fig. 3), probably in order to balance the overall visual effect of the architecture of the tomb and its decoration. The yellow colour is usually employed to render the main part of the door, which was doubleleafed (T.17, T.20; Fig. 4b), and its panels (T.15; Fig. 4a). Red, often bound by a narrow black band, is used for rendering the vertical doorjambs.

The doors sometimes preserve the imitation of metal nails, which held the woodwork together (T.17). ${ }^{46}$ The fragments recovered from the Hellenistic T.20 show that the door here had more colours as well as other details (nails and perhaps a key), unfortunately difficult to identify. The uniform yellow ochre colour does not indicate the material out of which the doors were made (wood or stone/marble), but the colour in which they were over-painted. In the case of T.12, the remnants of plaster preserve residues of a false door in red. The quality and precision in detail of the Hellenistic examples is far superior to that of the Roman ones. A false door imitation could be proposed for the meagre fragments at the entrance of

46 Raptou 2007: 119. 


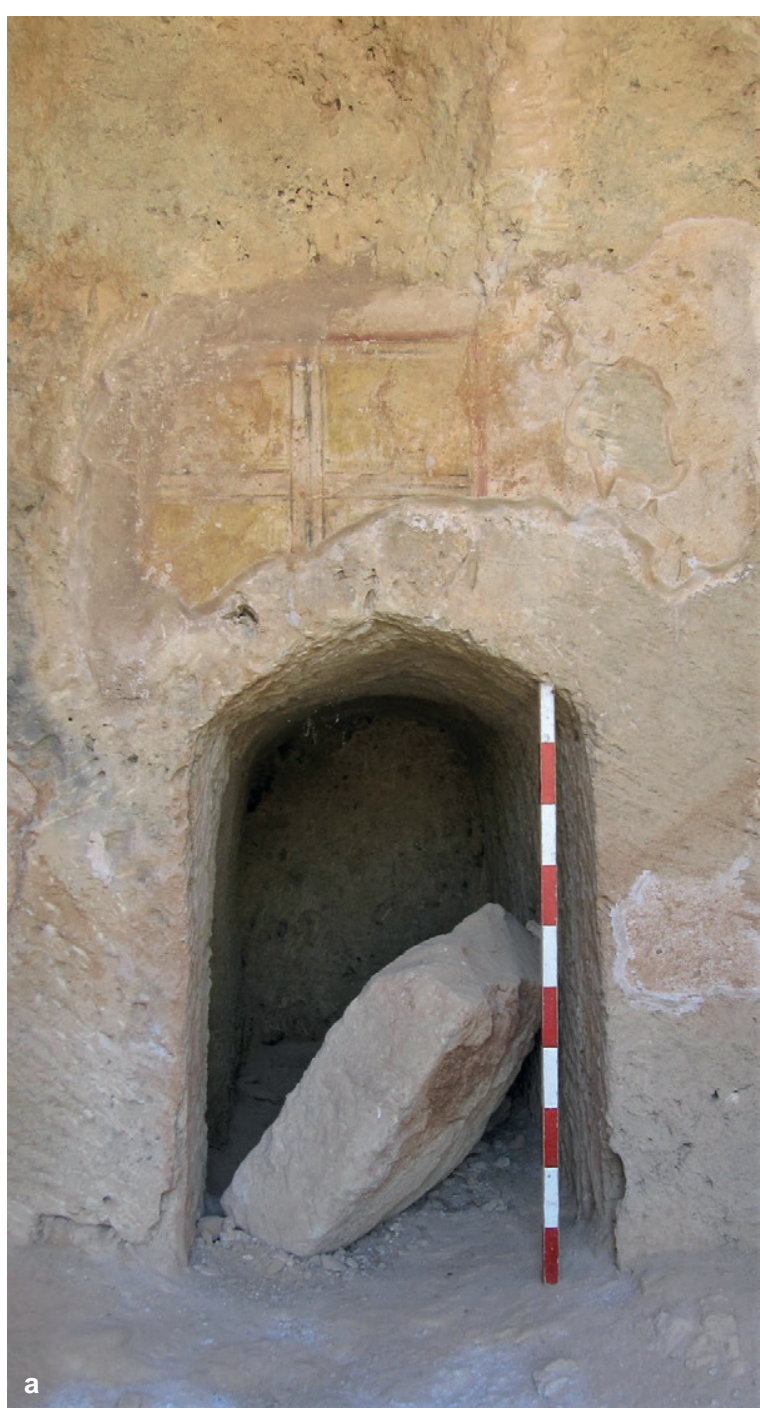

4a. Painted false door closing the entrance of a loculus in T.15; b. painted imitation of double-leafed door of T.20 (Phot. V. Lysandrou).

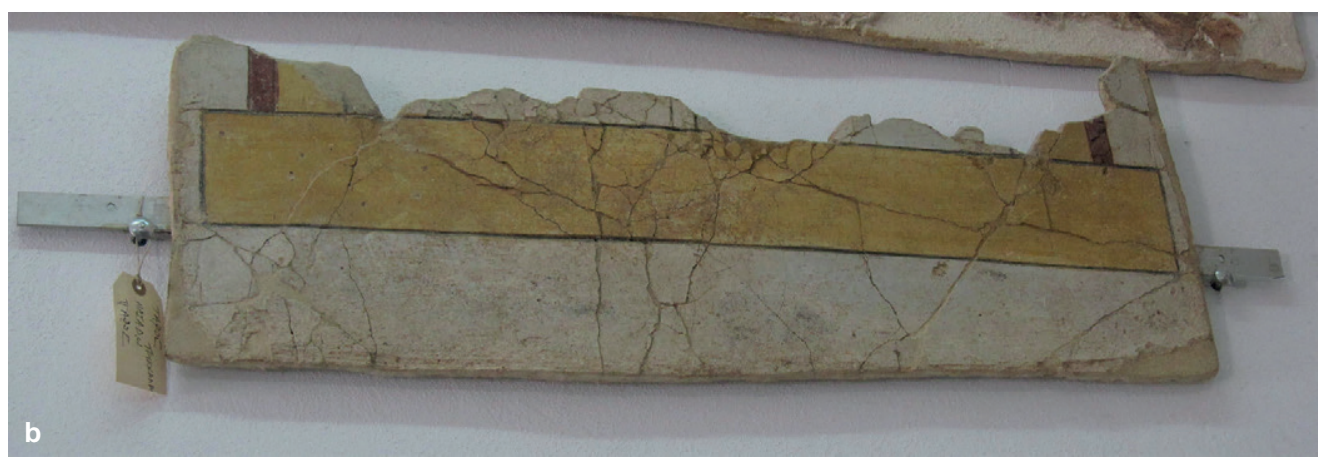




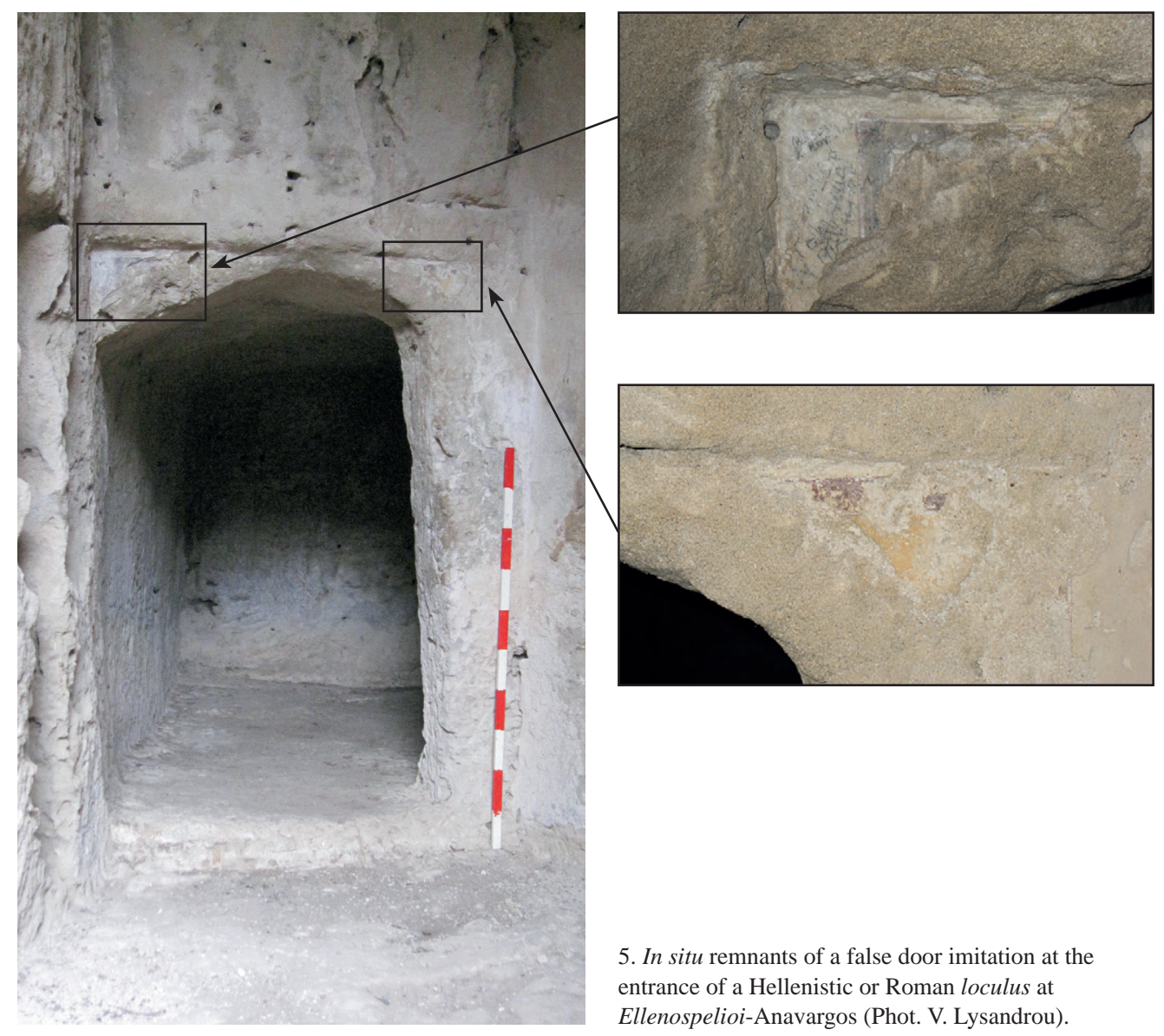

a Hellenistic or Roman loculus at Anavargos (Fig. 5) ${ }^{47}$ Generally speaking, this is a rather common motif in the tombs we are examining, ${ }^{48}$ as it is in Alexandria ${ }^{49}$ and elsewhere.

\section{ARCHITECTURAL ELEMENTS}

Representations of this kind, although abstracted, aim at giving the impression of real architecture. A prime example of this is the first phase of the rock-cut Hellenistic tomb T.3. Here, the walls of the square chamber were painted at regular intervals with fluted columns topped by Corinthian-type capitals carrying an egg-and-dart moulding, which went all around the tomb, below the ceiling - the whole giving the impression

\footnotetext{
${ }^{47}$ Lysandrou 2014: 275. The tomb is not located in Paphos and thus it is not included in Table 1.

${ }^{48}$ Another fragment of a very well-preserved door imitation with unknown provenance and no visible registration number, has been recently identified in the Paphos District Museum.

${ }^{49}$ Venit 2002: 16-18. See also Hypogeum A at Chatby: Venit 2002: 26-31 (with previous bibliography).
} 
of an atrium tomb of the type we see at the 'Tombs of the Kings'. Unfortunately, the loculi between pairs of columns ${ }^{50}$ were broken into long ago and nothing survives of what was represented on their front.

In $T .17,{ }^{51}$ the wall painting depicts wooden horizontal beams at the upper part of the vertical walls of the chamber for its entire perimeter. The veins of the wood are represented in an effort to make it appear more realistic.

Through the painted rendering of architectural elements, it was possible to depict valuable and hard-to-find materials, such as marble and alabaster, thus providing the tombs with a semblance of luxury at a relatively low cost. In addition, several wall paintings depict doors and other elements made of wood, as real wood would not have survived for long in the soil and climatic conditions of Cyprus. In order to achieve the desired result and to create as realistic an impression as possible of the material they wanted to represent, the artisans/artists carefully selected specific colours and shades (see Appendices). Thus, the wood is rendered in a vivid yellow colour, the iron nail-heads in light blue, while the texture and veins of the wood are depicted with red undulating lines on a yellow ochre background. ${ }^{52}$

For a better representation of these architectural elements, the painters were not limited to the simple application of colour: using a sharp tool they incised specific points in the mortar, so that the rendering of each motif is more realistic and convincing, at the same time emphasising the architectural character of the painted decoration. ${ }^{53}$ This is best seen in the imitation of isodomic masonry or of the panelling of wooden doors, where the joints or joining points are rendered by incisions (Figs $\mathbf{2 b} \mathbf{3} \mathbf{3}, \mathbf{4 a}$ ). The plaster incising in the context of wall painting often corresponds to the pointing of architectural elements and forms. In addition to their role for the better representation of these architectural elements, plaster incisions provided a sense of depth and consequently an imitation of three-dimensionality.

\section{OBJects}

Various objects are found represented in Cypriot tombs: household utensils, different kinds of pottery, an aryballos (T.21), strigils (T.21), rectangular boxes (pyxides? in T.4), a throne (T.4), disk-shaped objects (T.21), tabulae ansatae (T.8, T.22), ribbons, a cup (T.7), a bowl (T.7), nails (T.17), cords, mirrors (T.16, T.24), a flask (T.24), metal symposium vessels (oinochoe, table amphora in T.7) standing on a table (T.7?), possibly ritual objects (T.14), wheels (or loaves of bread? in T.21), a funerary stele (T.16?), as well as other objects that cannot be identified (T.10, T.24).

Ribbons are a widely used feature of funerary iconography. The Cypriot examples are usually rendered with red colour and are of various lengths and widths. They are represented

\footnotetext{
50 Michaelides 2004: 91.

51 Raptou 2007: 118-120.

52 Raptou 2007: 118-119.

${ }^{53}$ Michaelides 2004: 90.
} 
by themselves or with other motifs - most commonly for tying garlands and wreaths. It should be noted that wreaths and garlands are placed on the tympana of the arcosolia, thus emphasising their curvilinear shape (T.21).

The various objects depicted on the walls of the tombs hanging on painted nails and string (the hanging objects in the tympanum of T.4,,$^{54} \mathrm{~T} .21$ and T.24), clearly reflect the habit of hanging real offerings to the dead, in addition to those placed around the body. The practice is witnessed by real holes and nails on the walls of some tombs, from which such objects, garlands, wreaths and ribbons must have hung. Such nail holes were found in T.1, ${ }^{55}$ T.16, around the painted door of a loculus of T.20, and on the wall plaster fragments from the same tomb in Paphos District Museum..$^{56}$ Depicting everyday-life objects in the tombs must have been a funerary custom, given the many cases in which it is encountered. These objects were supposed to be used by the deceased in his/her new home, just like the grave goods placed inside the tombs.

\section{VEGETAL/FLORAL DECORATION}

Vegetal decoration usually consists of stylised renderings of plant shoots, including acanthus spirals, leaves, buds, and flowers. There are also more realistic renderings of palm fronds (T.23, T.26?), branches laden with fruit, and garlands of leaves, flowers, and fruit, where at least some of the fruits can be identified. These include pomegranates (T.4, T.16, T.21), bunches of grapes (T.10, T.21, T.24, T.27), an orang ${ }^{57}$ (T.16), and berries (T.21). Fruits such as pomegranates are also naturalistically represented by themselves, while myrtle leaves are generally realistically rendered (T.21).

Vegetal decoration, stylised or realistic, is a common theme in funerary art and decoration throughout antiquity, evoking the Elysian Fields or the Christian Paradise, depending on the period. ${ }^{58}$ It probably decorated all the Hellenistic and Roman painted tombs under consideration. ${ }^{59}$

${ }^{54}$ Recent research has revealed that the painted pyxis on the sarcophagus of T.4 was 'hanging' with a nail and string from the wall; see: Michaelides et al. forthcoming.

55 Michaelides et al. forthcoming.

56 Similar examples of painted hanging grave goods, as well as real $\Gamma$-shaped nails are found outside Cyprus; see: Pantermalis 1972: 157 for a Macedonian tomb in Vergina, where $\Gamma$-shaped iron nails were found at the spot where the garland was usually placed. Such painted nails from which hung weapons, helmets, and other warrior insignia, are depicted in the tomb of Lyson and Kallikles (Petsas 1966: 177, Fig. 43; Ginouvès et al. 1993: 178-179; Miller 1993: 38-39, 46, 48-55, Pls IIIa-b, 12e, 14b). Remains of copper nails were also found in tombs in Alexandria of Egypt (Venit 2002: 49, 70).

57 Raptou 2013: 280, 283.

58 Michaelides 2004: 94.

59 Some painted tombs listed in Table 2 appear not to include vegetal motifs, but we attribute this to the fragmentary preservation of their decoration. 


\section{ANIMAL DECORATION}

Few animals, real or mythical, are represented in the funerary wall paintings of Cyprus. To the first category belong birds: peacocks (T.7, T.21?), partridges (T.21, T.26), and other, difficult to identify birds (T.4, ${ }^{60}$ T.6), as well as a single dog (T.4) and fishes (T.4, T.21). The only mythical creatures known so far are griffins (T.1). The symbolism that birds and fish carry is well known and is universally used in the late Roman, early Christian and Byzantine periods. Birds represented together with vegetal motifs evoke paradisiacal gardens. ${ }^{61}$

\section{ANTHROPOMORPHIC DECORATION}

This category includes masks or human faces and full-length human figures. Such decoration, however, is not a common theme in the preserved painted tombs of Cyprus. T.27 had figural decoration, but as noted above ${ }^{62}$ the tomb was only partially investigated. The lower parts of two of the pendentives of the now collapsed dome, preserved the lower extremities of a standing human figure. Next to one of these there is a bunch of grapes, perhaps denoting a personification of autumn, and indicating that the pendentives were decorated with the four Seasons. The three vertically placed slabs that blocked the opening of an ossuary in T.10 were once covered with a painting. On two of these slabs, a female figure is depicted, short and not well proportioned, probably due to the reduced area available for decoration. She is richly dressed and bejewelled. A diadem, earrings, a necklace, and an armband can be seen. A young male figure appears to be depicted in T.9. Small parts of the face (Fig. 6a), the garments and the right foot (Fig. 6b) are preserved. Another standing figure, probably of a young man is depicted in T.16 framed by vegetal branches carrying pomegranates.

Female faces or masks are depicted hanging or placed between garlands of leaves and flowers in T.17. These are reminiscent of theatrical masks and may have a Dionysiac character since the god was associated with afterlife. ${ }^{63}$

\section{PAINTED INSCRIPTIONS}

There is evidence for five painted inscriptions coming from the Roman tombs of Cyprus. Only three of these, simple short greetings to the deceased, can be read. The longest is found in the centre of an arcosolium in T.22, where, within a painted tabula ansata, there

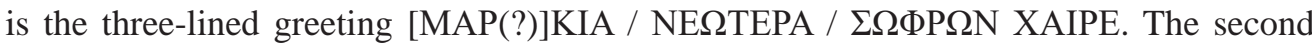
inscription comes from T.10 and is written below the feet of the standing female figure. It is fragmentary and aside from some isolated letters, the greeting XPH $\Sigma T[H] \mathrm{XAIPE}$ is

\footnotetext{
${ }^{60}$ Recent research has identified probably a pair of confronted peacocks; see: Michaelides et al. forthcoming.

${ }^{61}$ For the symbolism of birds and fish, see: Wood Conroy 2006: 338-340; Raptou 2007: 122, for the peacocks.

62 See above, footnote 38.

${ }^{63}$ Raptou 2007: 119.
} 

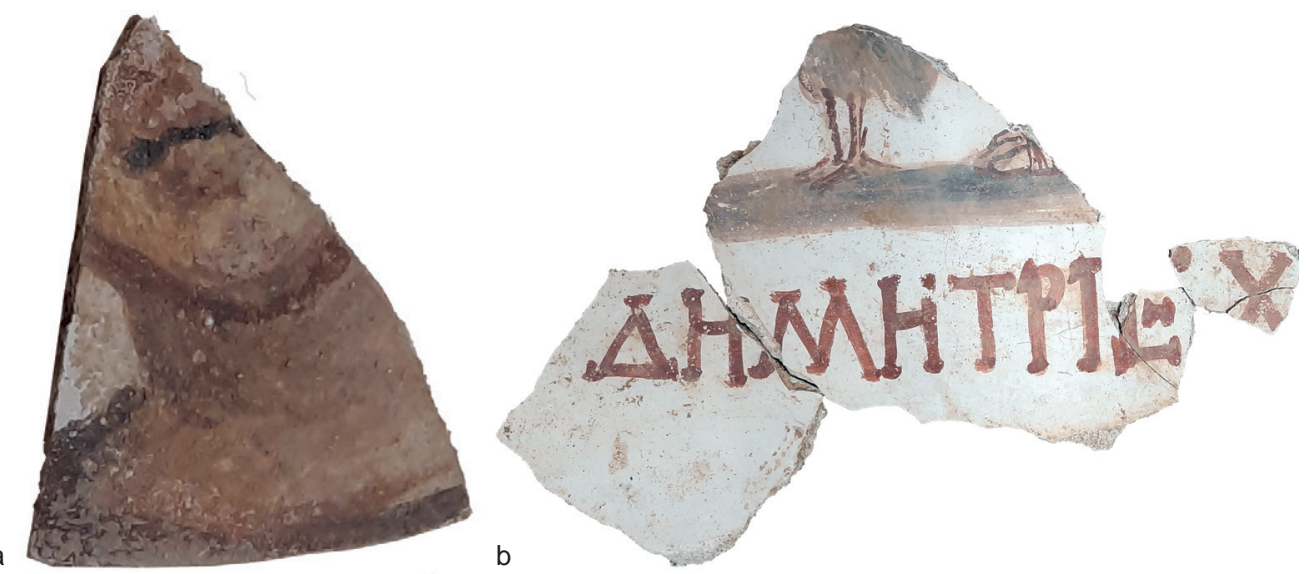

6. Wall painting fragments of T.9 with a figure (a), and a painted inscription (b); not to scale (Phot. V. Lysandrou).

also preserved. This formula is frequently found inscribed on cippi and stelae especially on the south coast of Cyprus (Amathus, Kition), but these are the only known examples in painting and in the Paphos region. ${ }^{64}$ The third painted inscription comes from T.9 and is even more fragmentary. It is found under the right foot of a figure: $\triangle$ HMHTPIE X[- and is probably part of another such greeting (Fig. 6b). A similar case to T.22, is found in T.8. Again, in the tympanum of an arcosolium there is a tabula ansata preserving traces of an alphabetic inscription, unfortunately far too worn and thus unreadable. Also unreadable were probable alphabetic letters within a partially preserved tabula ansata at Ayios Yeoryios Peyeias. ${ }^{65}$ For the sake of completeness, we mention that above the entrance to the rock-cut T.11 of the 'Tombs of the Kings', a tabula ansata in relief bears traces of plaster and must have once carried an inscription. ${ }^{66}$ The same can be proposed for a small relief of two columns carrying a pediment above the entrance of the now-destroyed rock-cut T.25 in the Eastern necropolis.

\section{THE MAKING OF THE WALL PAINTINGS}

Technology, technique, and style are interrelated elements, and, with the collective study of these three aspects, wall painting decoration can be better understood, especially since style is determined by the technique and vice versa. Thus, we will briefly present an overview of the materiality of the tombs' wall paintings in terms of the process of their manufacture. This section starts with a general overview of the paintings' materiality, evidence of which does not always survive in Cyprus. This is followed by the colour recording of wall

\footnotetext{
${ }^{64}$ Nicolaou 1987: 180; 2004: 268-269; Michaelides 2004: 95; Raptou 2004; 2007: 120-121.

65 Anastasiadou 2000: 336, Fig. 2 (Tomb 19).

${ }^{66}$ Unfortunately, nothing of this tabula ansata can be seen today.
} 
paintings of specific Cypriot tombs, mineralogical analyses of selected samples, and, lastly, observations on the mortars used. This section is accompanied by two appendices: Appendix I - Colour documentation/recording, and Appendix II - Pigments and mortars.

\section{OVERVIEW OF THE MATERIALITY OF THE TOMBS WALL PAINTINGS}

Only a limited number of materials analyses have been carried out on the tomb wall paintings of Cyprus. ${ }^{67}$ The combination of the results of these with those of the analyses completed in the context of the present research, allow for new observations to be made.

The three basic techniques used for the making of wall painting are fresco, secco and mezzo fresco, i.e. fresco technique with secco finishing. ${ }^{68}$ In the fresco technique, the artist places colours with water on the still wet plaster rich in lime (calcium hydroxide). The colours combine with water and the pigments penetrate, stabilise, and become an integral part of the plaster, thus creating a single whole, very durable over time. The secco technique differs in that the colours are applied on a dry surface. In this case, it is necessary to use a binder, which will hold the paint in place. Mezzo fresco is a mixed technique, where the colours are placed on a surface, which has partially dried. In this case, the colours do not penetrate as deeply as in the fresco technique, so the use of a binder is recommended.

In literature, the term fresco has prevailed with regard to the wall paintings of Cyprus. However, it seems that this term, which implies a specific manufacturing technique, may not always be appropriate. ${ }^{69}$ From the observations made in the context of the present research, it appears that in some cases the technique followed was that of secco or perhaps fresco technique with secco finishing. In some cases, the use of the fresco technique could be excluded even by macro-observation. Based on various factors, such as the colours, which lack the brightness and stability of the fresco, the way the painting strata have peeled off, and the exposure of the lower painting surfaces advocate for the use of other techniques. At the same time, the fact that in some cases the lime of the coating has not been impregnated with the pigments, ${ }^{70}$ but retains its white colour, is a further indication that the technique used could be other than exclusively the wet-on-wet application, i.e. fresco. ${ }^{71}$

Given the limited study of the subject in Cyprus and the relatively small number of preserved wall paintings, little is known about the execution of either the preparatory layers or the painted surface itself. In the work carried out, two types of incisions on the surface of the mortar have been observed. Deep incisions betray some kind of preparatory plan or division into sections of the area to be painted (see below Appendix II, Fig. 12b). Shallower incisions are usually guidelines for the actual decoration. For example,

\footnotetext{
${ }^{67}$ Kakoulli 1997; Kakoulli, Michaelides 2000; Kakoulli 2002; Wood Conroy, Atkinson 2004: 294-299; Kakoulli, Fischer, Michaelides 2010; Radpour, Fischer, Kakoulli 2019.

${ }^{68}$ Kakoulli 2009b: 27-28.

${ }^{69}$ For a review on variables affecting ancient paintings media analysis, see: Cuní 2016.

${ }^{70}$ Hadjistephanou 2016: 386.

${ }^{71}$ See Vitr., De arch. VII.3.7-8, where the difference between secco and fresco painting technique is explicitly described.
} 
on the ceiling of T.3, the fresh plaster was incised with a grid of small squares, which guided the artist to paint the precision-demanding band of meanders and squares. ${ }^{72}$ As mentioned earlier, even deeper incisions are themselves part of the design, underlining the architectural character of the decoration. Such incisions are found in tombs T.1, T.15, T.16, T.17 and on the fragments of T.20 (Figs 3, 4a). The presence of multiple guiding incisions would further support the use of the mezzo fresco or secco technique over that of fresco: the surface was prepared and then incised, and the painting would start when the plaster was still wet or semi-dry and continue until the plaster was completely dry, especially when the colour was applied in successive layers. Another way would be to cover the background with a single colour over which the multi-coloured designs or the gradations of representations were then painted. Shades and hues of a given colour were used in order to render details 'three-dimensionally' and give the illusion of depth and perspective. This is clearly seen on the fluting of the painted columns in T.3 (Fig. 7).

The entire process of wall paintings manufacturing technology includes three general parts: the preparation of the supporting body, the application of the plaster substrate/substrates and lastly, the execution of the painted decoration. In the specific case of wall paintings within a tomb structure, the supporting body on which the next layers are fixed, is defined as the surface of the natural bedrock (when the tomb is rock cut) or the structured wall (if the tomb is built). On the supporting body the preparatory stratum (base) is then applied, which is defined as the receiving surface of the painted decoration. The base essentially consists of one or more preparatory layers (substrates). This is the coating that comes between the body and the painting. The most common components of coatings applied to the carrier body were lime and sand, which were mixed with water to form the mortar. A key factor in the durability of the plaster and consequently of the painted decoration is the solid consistency between the preparation layer and the supporting body, due to mechanical bonds between them, and this is achieved by creating anchors for the most effective penetration of the mortar into the carrier. The laboratory analysis carried out on some of the Paphos tomb wall paintings showed that one and two preparatory layers (arriccio and intonaco) were usually used, in contrast to what was practised in the houses where up to four such layers are observed. ${ }^{73}$ Usually, on particularly uneven surfaces, more, sometimes thicker layers were applied. The first preparatory layers include larger pieces of aggregate, and all layers tend to become thinner the closer they are to the painted face of the wall. It has also been observed that, where the lower part of a wall painting is preserved, the plaster layer/s are thicker and become thinner as they progress up the wall. This is common practice employed mainly in order to provide support to the plaster.

Last in the process was application of the painted decoration. This painted surface consists of pigments, which usually come from natural minerals, and a binder, depending on the technique employed.

\footnotetext{
72 Michaelides 2004: 92.

${ }^{73}$ Kakoulli 1997: 136.
} 


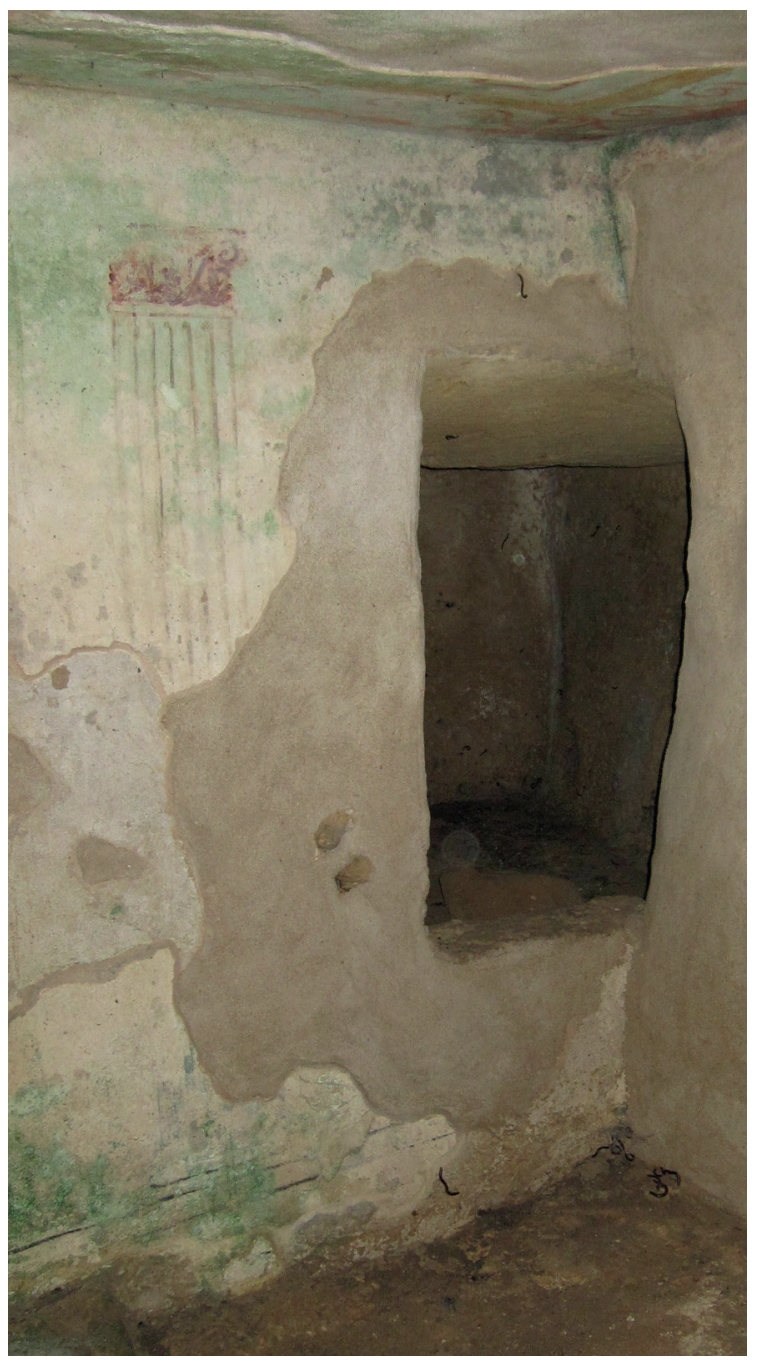

7. The upper part of a Corinthian-style column in T.3 (Phot. V. Lysandrou).

\section{COLOUR RECORDING ${ }^{74}$}

\section{MATERIALS AND METHODS}

For the accurate colour interpretation of pigments based on widely recognised codes, and with the ultimate goal of creating a database of the colours used in Hellenistic and Roman tombs in Cyprus, colorimetric analysis of visible pigments was performed with the use of a portable spectrophotometer. The colour documentation was carried out in most of the painted tombs which retained part of their decoration, and for which

\footnotetext{
${ }^{74}$ For the colour documentation/recording of the Hellenistic and Roman tombs of Paphos, see Appendix I.
} 
permission was granted by the Department of Antiquities (see Table 1). It also included fragments which are stored in the Paphos District Museum and in the Department's conservation laboratory.

The colours were first registered macroscopically and divided into groups. An indicative number was then selected from each group for colorimetric analysis. Measurements were taken using the Konica Minolta portable spectrometer, model CM-2600d. This instrument is capable of simultaneous measurements of SCI (Specular Component Included) and SCE (Specular Component Excluded) in a time of 1.5 seconds. In addition, its measurements are particularly accurate, and it offers the choice of two measurement diameters, 3mm and $8 \mathrm{~mm}$, depending on the object being measured and the characteristics to be measured, while allowing measurements at a wide range of angles. This method of colour recording, although direct, is non-destructive to the object examined.

The most common application of this instrument is the measurement of light absorption. A beam of light is sent from the device to the tested material, the light reflection is quantified, and the results are displayed on the device screen either numerically or graphically. For the needs of the present research, the Munsell colour notation was chosen for the recording of the results, as it is widely used in an archaeological context for identification of colours, either of soils (archaeological layers, clay, etc.) or of painted objects and painted decoration in general. The colour characterisation based on the Munsell chart was done by measuring the hue, the degree of saturation (chroma) and the brightness (value). So, the results provided by each measurement, relate to the values of the three components of each colour (hue/value/chroma).

In order to obtain the most reliable results during the colour recording, an attempt was made to avoid certain factors, which could distort the results of the measurements. Therefore, the painted parts to be measured were carefully selected and these included: areas which had not undergone conservation treatment (in which case the colours would have been altered by the addition of foreign materials) and areas where the colour or gradation was more compact (otherwise the colour of the substrate would distort the results). Areas that were particularly worn, peeling or pulverised were avoided, as were patches that had undergone chromatic alteration due to various natural degradation factors.

\section{RESULTS AND OBSERVATIONS ON THE COLOUR RECORDING}

Colours were recorded in seventeen tombs, and the results were registered in tables specially designed for the purpose. Table 3 in Appendix I, presents the measurements from just one tomb as an example. Table 4 in Appendix I, groups the colours and the various gradations recorded in each tomb, and the corresponding Munsell value. An attempt was made to determine both the basic and the mixed colours, so that safe conclusions can be drawn about the range of colours used.

From the numerous colour measurements taken and from the comparisons made between them, we observe the widespread use of some basic colours also identified macroscopically, such as white (pigment), white/off-white (preparatory layer), black, cyan, green, yellow and red. Through admixtures, these basic colours could cover the entire range of colour 
gradations, with more or less density in the colour and from the maximum to the minimum possible brightness, allowing the artist to use a wide colour palette. As such, colours like pink, purple, brown, etc. followed the basic ones.

In many cases the measurements allowed us to understand the use of pure colours. ${ }^{75}$ Equally common, however, seems to have been the habit of mixing some colours with others, with the aim of obtaining gradations. As shown by the results, some paints were not used pure or were based on another pigment and not the substrate. Thus, a light gradation was achieved by mixing the base pigment with white, or a dark gradation by adding yellow ochre or red. Another practice that was observed is that of over-painting at given points (in secco). This over-painting was also verified by the laboratory analyses that follow.

\section{PIGMENTS AND MORTARS ${ }^{76}$}

\section{MATERIALS AND METHODS}

For a more complete documentation and understanding of the manufacturing technology of these wall paintings, and specifically for the identification and quantification of the pigments used for creating the painted decoration - and also of the substrates - microscopic and mineralogical analyses were performed on an indicative number of fragments. For this purpose, three tombs were selected, T.7, T.9, and T.27 (see Appendix II). A selective sampling of thirty-one indicative fragments from their decoration was carried out (see Table 5). The main selection criterion was their representativeness in relation to the corresponding painted decoration. Moreover, the samples selected for analysis covered as much as possible of the colour spectrum established by the previous colour recordings.

Initially, these samples were photographed and examined both macroscopically and microscopically. The stereoscopic observation showed that each sample consists of successive layers of (starting from the bottom) mortar, coating and pigment (one or more). The final sampling points were then selected for their processing and preparation for mineralogical analysis. A small amount of the colour was taken from the surface of each sample, which was pulverised by hand until homogeneous. This second phase of sampling was done with great care and sought to isolate as clean a quantity of pigment as possible, without mortar fragments.

The mineralogical composition of each sample was determined in a randomly oriented powder preparation using X-ray diffraction (XRD). For the study, copper X-ray irradiation was used, with a wavelength of $1.54056 \AA$ and a Ni filter of $0.0170 \mathrm{~mm}$, to isolate monochromatic X-ray irradiation on a Philips PW1710 diffractometer. ${ }^{77}$ The quantification (\%) of the mineralogical phases was based on the enumerations of their specific reflections and took into account the density and the mass absorption coefficient of the mineralogical

\footnotetext{
${ }^{75}$ For an explanation of the different terms used, see the following section.

${ }^{76}$ See Appendix II for the cards prepared for each sample discussed, which include all the accompanying information.

${ }^{77}$ For more information on the method and technical specifications, see: Lysandrou 2014: 292-294.
} 
phases for $\mathrm{Cu}(\mathrm{CuK} \alpha)$ radiation. The standard ICDD (International Center of Diffraction Data) diffraction cards were used as a database for the identification of the mineralogical phases. Individual special reports were prepared for each sample, with the necessary information and a detailed analysis of the results. Indicative examples are given in Appendix II. ${ }^{78}$

\section{RESULTS AND OBSERVATIONS ON THE PIGMENTS AND THE MINERALOGICAL ANALYSES}

On the basis of the material examined and the experimental measurements taken, we can propose that it is very likely that the mezzo fresco technique (i.e. fresco with secco finishing) was used for at least some of these wall paintings. Such a position can only be confirmed by further laboratory analyses.

The high concentrations of calcite, which are consistently documented in all samples, and the concentrations of gypsum, which are present in several of them, are the main mineralogical phases of the samples.

Calcite $\left(\mathrm{CaCO}_{3}\right)$, which occurs most frequently, is one of the most common minerals and its most common colour when in the form of powder is white. When the mineral contains impurities, it may exhibit other colours. The values of calcite recorded by the analyses are due to its use both in the substrate and the binder. The detected gypsum $\left(\mathrm{CaSO}_{4} \cdot 2 \mathrm{H}_{2} \mathrm{O}\right)$ is likely part of the coating and occurred during the paint layer sampling. The presence of gypsum may be due to the composition of the rock or may have been caused by weathering (salt crystallisation). Gypsum can be formed from interaction between sulphur (containing soluble salts) and the calcium from calcite, and crystallise at the subsurface of the painting, causing pitting and loss of paint. ${ }^{79}$ Studies made outside Cyprus, as for example in Egypt, ${ }^{80}$ have attributed the presence of gypsum in the mortar to the habit of using a gypsum solution as a mortar coating before the application of the paint layer.

Quartz, coming from the substrate, was also common in the samples examined. Quartz $\left(\mathrm{SiO}_{2}\right)$ is a colourless and clear mineral. It is insoluble in water and when it settles in rock cavities it forms various types of agglomerates. It is the main component of sands and gravel and shows great resistance to disintegration. Quartz was found in the samples as silicate sand, which is mixed with lime to create the mortar.

As for the pigments, they were securely identified in most samples, and their identification is in resonance with the colour characterisation made during macroscopic and stereoscopic examination (Appendix II, Table 5). Specifically:

- white pigment: calcite - found in samples 2 and 10;

- black pigment: magnetite - sample 13; hausmannite and vernadite - sample 6; amorphous organic carbon - sample 21;

- red pigment: hematite - samples 3, 4, 8, 14, 16, 21, 22, 24, 25, 28 and 29;

${ }^{78}$ Because of restrictions of space, only indicative samples are provided in the Appendices. The full results can be found in: Lysandrou 2014: 392-483.

${ }^{79}$ This view has been expressed in relation to analyses carried out on mural mortars from the ancient theatre of Paphos; see: Wood Conroy, Atkinson 2004: 294.

${ }^{80}$ Moussa et al. 2009. 
- green pigment: celadonite - samples 1, 5, 6, 11, 12, 23, 25, 29 and 31;

- yellow pigment: goethite - samples 7, 8, 11, 16, 17, 26 and 27;

- blue pigment: cuprorivaite (Egyptian blue) ${ }^{81}$ - samples 13, 15, 19 and 30.

Finally, it is worth noting that several samples (6, 8, 11, 13, 16, 21, 22, 25 and 29; see below Appendix II, Figs 8b, 18a-b, 19a-b), had two pigments while in two cases (samples 25 and 29; see below Appendix II, Figs 18a-b, 19a-b) two distinct successive layers of green and red were identified. Pigment mixing, such as goethite yellow and hematite red, to give a pink hue was also observed.

From the above, it can be surmised that the ancient painters in Cyprus had a range of different pigments on their palette, which were processed in order to achieve the desired results. The numerous colour shades documented, result from mixing the different pigments. The addition of white calcite created lighter shades of a given colour, while mixing with dark pigments gave the opposite effect. Also, in addition to mixing the pigments before applying them to the surface to be painted, the current research showed that the painters used to apply pure pigments in successive layers in order to achieve the desired aesthetic and colour results.

It appears that some of the detected pigments were used more frequently than others, forming the backbone, so to speak, of the wall painting, while other pigments or mixtures of pigments were used for secondary areas that required special treatment, such as shading or gradations for successfully creating a sense of perspective. In conclusion we can say that the study has shown that the numerous colours and colour shades used in the three tombs selected (T.7, T.9 and T.27), were essentially created with the use of only six basic pigments (Appendix II, Table 6).

\section{OBSERVATIONS ON THE MORTARS}

The macroscopic and microscopic study of the mortars used in these three tombs highlighted some differences in their composition. In some samples, the use of rounded aggregates was observed (see below Appendix II, Figs 10d, 13b), while others contained coarse sand. ${ }^{82}$ This observation relates to the manufacturing technology of wall paintings and merits further study. The traces of carbon in the mortar of all three tombs is also part of their manufacturing technology. These may be due to residues because of lime processing (see below Appendix II, Fig. 16b). In T.27 the presence of carbon is different and could be attributed to the manufacturing method used. It has been shown

${ }^{81}$ Egyptian blue is a synthetic blue pigment made up of a mixture of silica, lime, copper, and an alkali. Its colour is due to a calcium-copper tetrasilicate $\mathrm{CaCuSi}_{4} \mathrm{O}_{10}$ of the same composition as the naturally occurring mineral cuprorivaite; see: Hatton, Shortland, Tite 2008; Kakoulli 2009a. For its presence specifically in T.27, see also: Kakoulli 1997: 133. See also: Hadjistephanou 2016:386; 'Copper is the metal of Cyprus and the main constituent in the production of Egyptian blue, an important color frequently encountered in tombs, despite its rarity’. For its presence in a number of Paphian tombs, see: Michaelides et al. forthcoming.

${ }^{82}$ For a brief description on the plaster stratigraphy of T.23, T.26, and T.27, see also: Kakoulli 1997: 136. 
that ash was used in the mortars of Cypriot floor mosaics since Hellenistic times. ${ }^{83}$ Thus, this technology was known on the island and could have been applied in the making of wall paintings too.

In addition, the presence of carbonised material (fibre?), ${ }^{84}$ as well as its imprint, in samples from T.27 (see below Appendix II, Figs 8a, 19b), is also related to the production method and differentiates this tomb from T.7 and T.9. This is particularly interesting and further research can provide new insights into the manufacturing technology of Roman funerary wall paintings.

\section{CONCLUSIONS}

The subterranean tombs of Paphos preserve considerable remains of wall paintings in situ - much more than the public and private buildings above ground. Nonetheless, the evidence is fragmentary and, so far, no complex mythological or other representations have been found - the human figures interpreted as possible Seasons in T.27 excepted. Thus, the present study was limited to discussion of the categories of motifs represented in these tombs and listing of tombs in which particular themes are encountered. This thematic listing does not claim to be complete, and we have not attempted either a stylistic analysis or an interpretation of the possible symbolism of each motif, although clearly some of them have a well-attested eschatological content and symbolism. The themes encountered in the wall paintings of tombs from the Hellenistic and Roman periods in Cyprus are usually repetitive. The known wall paintings do not depict scenes directly related to death, burial ceremonies, or the afterlife, and they do not reveal any specific information about the ceremonial burial procedures. However, the symbolism of various motifs employed can be associated with death and the deceased.

It is clear that, as in the case of the architecture of some of the tombs, the wall paintings decorating them try to evoke an ambiance reminiscent of real life, betraying a perception of the tomb as the new dwelling of the dead in the afterlife. In fact, in the paintings decorating the tombs we do not find any themes directly connected to death or departure, but objects related to daily life, as well as imitations of architectural character.

Based on the results of laboratory analyses, it appears that there are no great differences between funerary and domestic or public wall paintings regarding the materials used. The pigments are the same as is the method of applying them, and so are the materials used for the substrates, although, as we have already observed, in the tombs one often encounters a simpler sequence of layers than that found in domestic wall paintings. Also, a common practice in domestic architecture, namely the herringbone incisions made on the last-but-one under-layer in order to ensure better adherence of the final, decorated layer of the paintings, does not seem to have been employed in tombs where, as we have mentioned, the support is generally simpler. No experimentations that deviate from the hitherto known

\footnotetext{
${ }^{83}$ Charalampous et al. 2009.

${ }^{84}$ Straw fibres are reported in the wall paintings of some sites in Nea Paphos; see: Hadjistephanou 2016: 386.
} 
funerary wall painting norm are attested in the samples examined, something that shows that the craftsmen and artists of the time had a deep knowledge, tested and established, of the materials available and the way they were used. However, more research into the composition of the substrata of funerary wall paintings and comparison with the Hellenistic and Roman public and private wall painting manufacturing technology needs to be carried out and studied within the chronological context of the decoration.

\section{Acknowledgements}

The present article combines some of the results of the first author's unpublished $\mathrm{PhD}$ dissertation (Lysandrou 2014; academic supervisor: Professor Demetrios Michaelides), with the second author's observations from many years' study of the wall paintings. Cordial acknowledgments go to the Department of Antiquities of Cyprus and its former Director Dr Maria Chatzikosti, and the former Deputy Directors Drs Marina SolomidouIeronymidou and Despo Pileidou, for granting all necessary permissions. We also thank the present Director of the Department, Dr Marina Solomidou-Ieronymidou for permission to continue our study of the tombs, and we are grateful to Archaeological Officer Dr Eustathios Raptou for the consent to visit and study tombs excavated by him. Special thanks are due to Conservator at the Department of Antiquities Dr Eleftherios Charalambous for his invaluable support in the study of pigments and mortars during the 2010 survey. We express our warm appreciation to Dr Eleftherios Charalambous and Mr Nikodemos Demetriou, who accompanied us on several of our visits to the tombs. In addition, we express our thanks to the Department of Chemistry of the Aristotle University of Thessaloniki and Professor Ioannis Stratis for providing the portable spectrometer used during the 2010 survey for the colorimetric analysis of the wall paintings, as well as Dr Nikolaos Kantiranis, Lecturer in the Geology Department of the School of Sciences of the Aristotle University of Thessaloniki for the mineralogical analysis of the samples.

\section{References}

Alabe, F. 2002: Décors peints au plafond dans des maisons hellénistiques à Délos, $B C H$ 126/1, 231-263

Anastasiadou, T. 2000: The rock-cut tombs at Agios Georgios tis Pegeias, RDAC 2000, 333-347

Charalampous, E., Charalampous, A.Ch., Pavlidou, E., Stratis, I. 2009: I chrisi tou koniamatos sta ypostromata ton epidapedion psiphidoton tis Kyprou, RDAC 2009, 549-604

Cuní, J. 2016: What do we know of Roman wall painting technique? Potential confounding factors in ancient paint media analysis, Heritage Science 4/44, 1-13

Di Vita, A. 1986-1987: Atti della Scuola 1986-1987, ASAA LXIV-LXV, 435-534

Ginouvès, R., Akamatis, I., Andronicos, M., Despinis, A., Drougou, S., Guimier-Sorbets, A.-M., Hatzopoulos, M., Kahil, L., Karamitrou-Mendessidi, G., Lazaridou, K.D., Pandermalis, D., Picard, O., Sakellariou, M. 1993: La Macédoine de Philippe II à la conquête romaine, Paris 
Guimier-Sorbets, A.-M. 2009: L'iconographie des mosaïques hellénistiques de Chypre, CCEC 39, 141-152

Guimier-Sorbets, A.-M., Michaelides, D. 2009: Alexandrian Influences on the Architecture and Decoration of the Hellenistic Tombs of Cyprus, [in:] Michaelides, D., Kassianidou, V., Merrillees, R.S. (Eds), Proceedings of the International Conference Egypt and Cyprus in Antiquity, Nicosia, 3-6 April 2003, Oxford, 216-233

Hadjisavva, M. 1982: A Coloured Guide to the Tombs of the Kings, Nicosia

Hadjisavvas, S. 1982: A Unique Roman Built Tomb in Paphos, RDAC 1982, 202-206 Hadjisavvas, S. 1985: Excavations at the 'Tombs of the Kings' - Kato Paphos, [in:] Karageorghis, V. (Ed.), Archaeology in Cyprus 1960-1985, Nicosia, 262-268 Hadjisavvas, S. 1988: Makedonikes epidraseis stin taphiki architektoniki tis Paphou, [in:] Ninou, A., Kypraiou, E. (Eds), Praktika tou XII Diethnous Synedriou Klasikis Archaiologias [Athina 4-10 Septemvriou 1983], tomos D', Athina, 237-238

Hadjisavvas, S. 1998: Makedonia-Kypros. Apo ton Alexandro os ti Romaiki kataktisi, [in:] Anastasiadis, A. (Ed.), Kypros kai Makedonia. Scheseis mesa sto chrono, Leukosia, 13-65

Hadjisavvas, S. 2012: Anaskaptontas tous taphous ton Vasileon, Leukosia

Hadjisavvas, S. forthcoming: The Contribution of the Excavations at the 'Tombs of the Kings' (Palaiokastra) to the History of Paphos, [in:] Balandier, C., Michaelides, D., Raptou, E. (Eds), Nea Paphos and Western Cyprus. Proceedings of the Colloquium, [Paphos 11-15 October 2017], Bordeaux

Hadjisavvas, S., Flourentzos, P. (Eds) 2007: ARDA for the year 2001, Nicosia Hadjistephanou, E. 2016: Practical Approaches in the Conservation of Wall Paintings in Nea Paphos, [in:] Balandier, C. (Ed.), Nea Paphos. Fondation et développement urbanistique d'une ville chypriote de l'Antiquité à nos jours. Études archéologiques, historiques et patrimoniales. Actes du $1^{\text {er }}$ colloque international sur Paphos, Avignon 30, 31 Octobre et $1^{\text {er }}$ Novembre 2012, Ausonius Mémoires 34, Bordeaux, 375-391

Hatton, G.D., Shortland, A.J., Tite, M.S. 2008: The production technology of Egyptian blue and green frits from second millennium BC Egypt and Mesopotamia, JAS 35/6, 1591-1604

Kakoulli, I. 1997: Roman wall paintings in Cyprus: A scientific investigation of their technology, [in:] Béarat, H., Fuchs, M., Maggetti, M., Paunier, D. (Eds), Roman Wall Painting: Materials, Techniques, Analysis and Conservation. Proceedings of the International Workshop Fribourg 7-9 March 1996, Fribourg, 131-141

Kakoulli, I. 2002: Late Classical and Hellenistic painting techniques and materials: a review of the technical literature, Reviews in Conservation 3, 56-67

Kakoulli, I. 2009a: Egyptian blue in Greek painting between 2500 and 50 BC, [in:] Shortland, A.J., Freestone, I.C., Rehren, T. (Eds), From Mine to Microscope: Advances in the Study of Ancient Technology, Oxford, 79-92

Kakoulli, I. 2009b: Greek Painting Techniques and Materials from the Fourth to the First Century BC, London 
Kakoulli, I., Fischer, Ch., Michaelides, D. 2010: Painted rock-cut tombs in Cyprus from the Hellenistic and Roman periods to Byzantium: material properties, degradation processes and sustainable preservation strategies, Studies in Conservation 55/Supp. 2, 96-102 Kakoulli, I., Michaelides, D. 2000: Technological investigation of monumental GraecoRoman tomb paintings in Cyprus, [in:] 32 International Symposium Archaeometry, Mexico, s. p.

Karageorghis, V. 1966: Chronique des fouilles et des découvertes archéologiques à Chypre en 1965, ВСH 90/1, 297-389

Karageorghis, V. 1975: Chronique des fouilles et découvertes archéologiques à Chypre en 1974, BCH 99/2, 801-851

Karageorghis, V. (Ed.) 1975: ARDA for the year 1974, Nicosia

Karageorghis, V. 1976: Chronique des fouilles et découvertes archéologiques à Chypre en 1975, BCH 100/2, 839-906

Karageorghis, V. 1980: Chronique des fouilles et découvertes archéologiques à Chypre en 1979, BCH 104/2, 761-803

Karageorghis, V. (Ed.) 1980: ARDA for the year 1979, Nicosia

Karageorghis, V. 1982: Chronique des fouilles et découvertes archéologiques à Chypre en 1981, BCH 106/2, 685-744

Karageorghis, V. (Ed.) 1982: ARDA for the year 1981, Nicosia

Karageorghis, V. 1984: Chronique des fouilles et découvertes archéologiques à Chypre en 1983, BCH 108/2, 893-966

Karageorghis, V. (Ed.) 1984: ARDA for the year 1983, Nicosia

Karageorghis, V. 1985: Chronique des fouilles et découvertes archéologiques à Chypre en 1984, BCH 109/2, 897-967

Karageorghis, V. (Ed.) 1985: ARDA for the year 1984, Nicosia

Karageorghis, V. 1986: Chronique des fouilles et découvertes archéologiques à Chypre en 1985, BCH 110/2, 823-880

Karageorghis, V. (Ed.) 1986: ARDA for the year 1985, Nicosia

Karageorghis, V. 1987: Chronique des fouilles et découvertes archéologiques à Chypre en 1986, ВСH 111/2, 663-733

Karageorghis, V. 1989: Chronique des fouilles et découvertes archéologiques à Chypre en 1988, BCH 113/2, 789-853

Karageorghis, V. (Ed.) 1989: ARDA for the year 1988, Nicosia

Loulloupis, M. (Ed.) 1992: ARDA for the year 1991, Nicosia

Lysandrou, V. 2014: I taphiki arkhitektoniki kata tin Ellinistiki kai Romaïki periodo stin Kipro, unpublished PhD thesis, University of Cyprus, Nicosia

Mavrojannis, T. 2016: The Mausoleum of Ptolemy Eupator and the 'Tombs of the Kings' at Nea Paphos in the Light of the Portraiture of the Ptolemaic Strategoi of Cyprus from Voni-Kythrea, Ostraka, Rivista di antichitá XXV, 119-163

Michaelides, D. 1995: Chypre Hellénistique et Romaine, DossArch 205, 106-115

Michaelides, D. 2001: Archeologia Paleocristiana a Cipro, [in:] Farioli Campanati, R. (Ed.), XLIV Corso di Cultura sull’Arte Ravennate e Bizantina. Seminario Internazionale 
di Studi sul tema: Le grandi isole del Mediterraneo orientale tra tarda antichità e medioevo, Ravenna, 179-239

Michaelides, D. 2004: Cypriot Painted Tombs and their Ceilings, [in:] Borhy, L. (Ed.), Plafonds et voûtes à l'époque antique. Actes du VIIIe Colloque international de l'Association Internationale pour la Peinture Murale Antique [Budapest-Veszprém, May 15-19, 2001], Budapest, 89-96

Michaelides, D. 2005: Brief reflections on two new ‘Cypriot' mosaics, [in:] Morlier, H. (Ed.), La mosaïque gréco-romaine IX. Actes du IX Colloque international pour l'étude de la mosaïque antique et médiévale. Association Intenationale pour l’Étude de la Mosaïque Antique (AIEMA) [Rome 5-10 November 2001], CEFR 352, Rome, 399-404

Michaelides, D. 2014: The Significance of the Basilica at Agioi Pente of Yeroskipou, [in:] Stewart, Ch.A., Davies, T.W., Weyl Carr, A. (Eds), Cyprus and the Balance of Empires. Art and Archaeology from Justinian I to the Coeur de Lion, ASOR Archaeological Reports 20, Cyprus American Archaeological Research Institute Monograph Series 5, Boston, MA, 1-16

Michaelides, D., Guimier-Sorbets, A.-M. 2016: Funerary Architecture and Other Underground Structures in Hellenistic Cyprus and Rhodes, CCEC 46, 305-322

Michaelides, D., Guimier-Sorbets, A.-M., Verri, G., Guimier, A. forthcoming: Re-examining some of the tomb paintings of Nea Paphos, [in:] Balandier, C., Michaelides, D., Raptou, E. (Eds), Nea Paphos and Western Cyprus. Colloquium [Paphos 11-15 October 2017], Bordeaux

Miller, S.G. 1993: The Tomb of Lyson and Kallikles: A Painted Macedonian Tomb, Mainz a/Rhein

Młynarczyk, J. 1990: Nea Paphos in the Hellenistic period, Nea Paphos III, Varsovie Moussa, A.M.A., Kantiranis, N., Voudouris, K.S., Stratis, J.A., Ali, M.F., Christaras, V. 2009: The impact of soluble salts on the deterioration of pharaonic and Coptic wall paintings at Al Qurna, Egypt: mineralogy and chemistry, Archaeometry 51/2, 292-308 Nicolaou, I. 1986: Inscriptiones Cypriae Alphabeticae XXV, 1985, RDAC 1986, 192-196 Nicolaou, I. 1987: Inscriptiones Cypriae Alphabeticae XXVI, 1986, RDAC 1987, 177-184 Nicolaou, I. 2004: Inscriptiones Cypriae Alphabeticae XLIII, 2003, RDAC 2004, 267-269 Nicolaou, K. 1966a: Archaeology in Cyprus, 1961-1966, ArchRep 12, 27-43

Nicolaou, K. 1966b: The Topography of Nea Paphos, [in:] Bernhard, M.L. (Ed.), Mélanges offerts à Kazimierz Michałowski, Warszawa, 561-601

Nicolaou, K. 1976: Archaeology in Cyprus, 1969-1976, ArchRep 22, 34-69

Pantermalis, D. 1972: O neos Makedonikos taphos tis Verginas, Makedonika 12, 147-182 Papageorghiou, A. 1990: Chronique des fouilles et découvertes archéologiques à Chypre en 1989, BCH 114/2, 941-985

Papageorghiou, A. (Ed.) 1990: ARDA for the year 1989, Nicosia

Papageorghiou, A. (Ed.) 1991: ARDA for the year 1990, Nicosia

Papageorghiou, A., Foulias, A. 2013: L'architecture funéraire à Chypre du $\mathrm{I}^{\mathrm{er}}$ au $\mathrm{X}^{\mathrm{e}}$ siècle, CCEC 43, 201-225 
Petsas, Ph.M. 1966: O taphos ton Leukadion, Athina

Radpour, R., Fischer, Ch., Kakoulli, I. 2019: New Insight into Hellenistic and Roman Cypriot Wall Paintings: An Exploration of Artists' Materials, Production Technology, and Technical Style, Arts 8/74, 1-33

Raptou, E. 2004: A Painted Roman Tomb at Paphos (P.M. 3510), MeditArch 17, 311-321

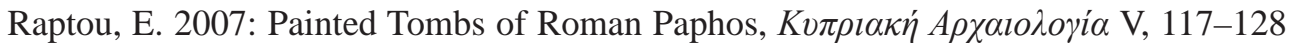

Raptou, E. 2009: Sarcophage attique trouvé à Paphos, RDAC 2009, 205-236

Raptou, E. 2013: Une nouvelle peinture funéraire de Paphos à décor symbolique, SAAC 17, 277-291

Rupp, D.W. 1978: A Hellenistic black and white pebble mosaic from the Acropolis of Kourion, RDAC 1978, 254-265

Rupp, D.W. 1982: Eustolios complex, [in:] Wylde Swiny, H. (Ed.), An archaeological guide to the ancient Kourion area and the Akrotiri Peninsula, Nicosia, 132-139

Venit, M.S. 2002: The monumental tombs of ancient Alexandria. The theater of the dead, Cambridge

Wood Conroy, D. 2006: Wall paintings in the Icarus Street Tomb, Pafos, [in:] Raptou, E., The Built Tomb in Icarus Street, Kato Paphos, RDAC 2006, 331-342

Wood Conroy, D., Atkinson, J. 2004: Roman Wall Paintings in the Pafos Theatre, RDAC 2003, 275-300 


\section{APPENDIX I: COLOUR DOCUMENTATION/RECORDING}

This appendix includes one example of the chromatic recording and Munsell coding chart of a tomb, namely T.27 (Table 3), which is indicative of the colour measurements taken for all seventeen tombs surveyed in 2010 or published before that year and listed in Table $\mathbf{1}$. At the top of the chromatic recording and Munsell coding chart is listed the basic information for a given tomb, such as its name and location, as well as the date and/or time of acquisition of the measurements. Although numerous measurements were made for every tomb, here we give only one for each of the basic colours and their gradations found in a single tomb. In the main part, the tables are divided into three columns. The first column indicates the serial number of colours marked also on the figures below, the second column records the colour of every measuring point as perceived by a visual description of the operator, the third and last column encodes the result based on the Munsell colour chart.

All measurements for each one of the basic colours for all seventeen tombs are shown in the collective Table 4 below. In this table 'colour' refers to visual macroscopic description, while 'Munsell indication' refers to the range of variation of the Munsell measurements, which is directly related to the pigment's deterioration, the binder and the substrate of each area from which the measurement was taken. 
Table 3. Example of chromatic recording of T.27

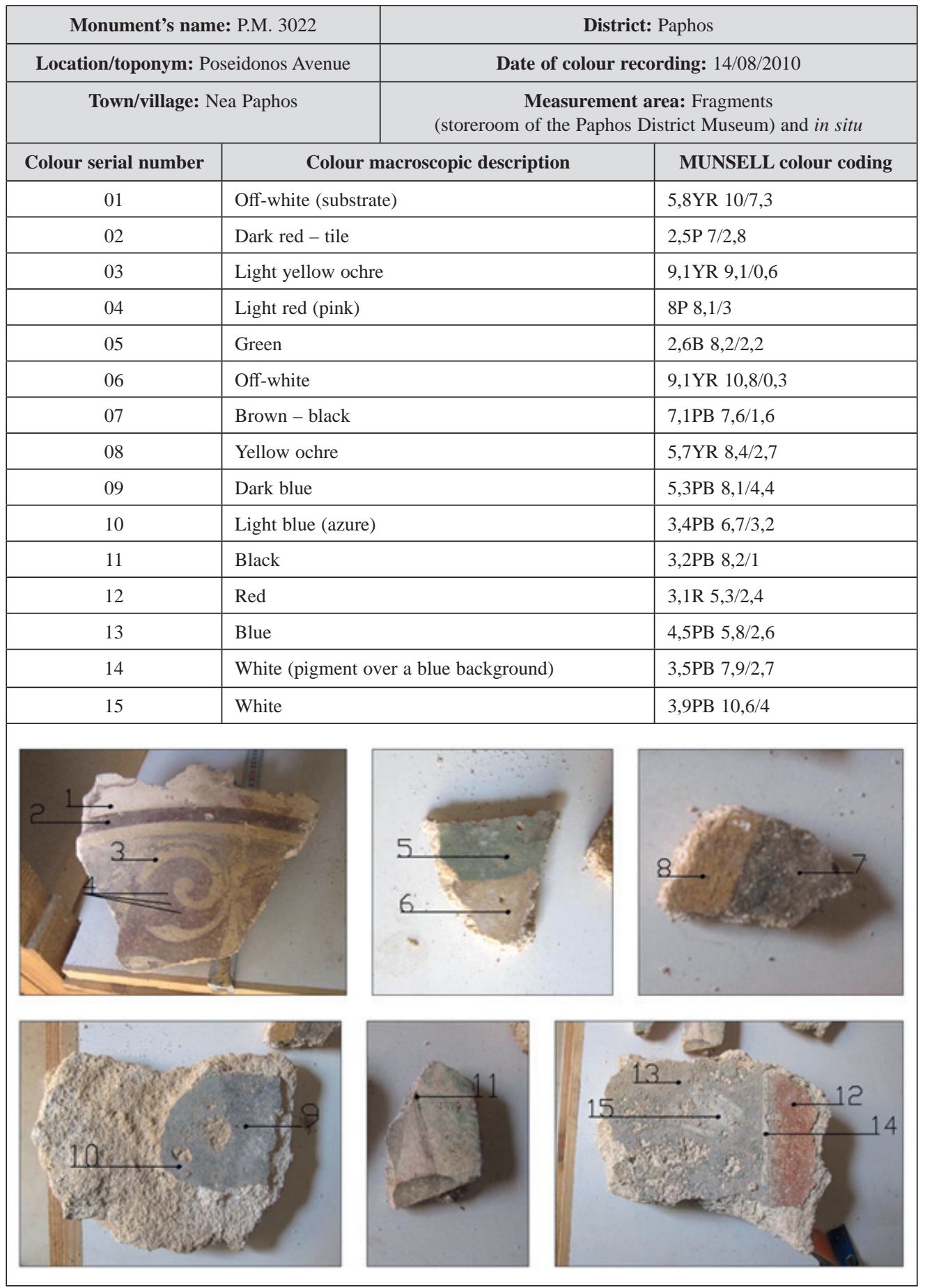




\begin{tabular}{|c|c|c|}
\hline Colour serial number & Colour macroscopic description & MUNSELL colour coding \\
\hline 01 & Dark blue & 9,2YR 5,9/1,3 \\
\hline 02 & Yellow ochre & 1,3Y 9,6/3,8 \\
\hline 03 & Red & 0,9YR 7,5/2,5 \\
\hline 04 & Off-white & $6 G Y 11,7 / 0,3$ \\
\hline 05 & Black & 3,3G 9,9/1 \\
\hline
\end{tabular}




\begin{tabular}{|c|c|c|c|c|c|c|c|}
\hline & 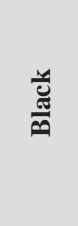 & 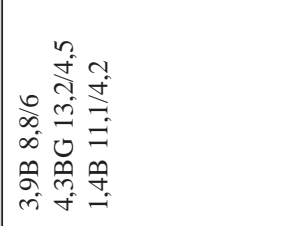 & 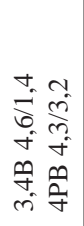 & $\begin{array}{l}\hat{m} \\
\delta \\
= \\
= \\
\approx \\
\tilde{N}\end{array}$ & $\begin{array}{l}\infty \\
\stackrel{\infty}{N} \\
\hat{N} \\
m \\
m \\
\sim\end{array}$ & $\begin{array}{l}\hat{n} \\
\hat{m} \\
\hat{m} \\
\hat{N} \\
\hat{N} \\
\sigma\end{array}$ & 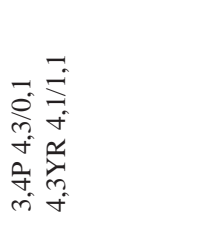 \\
\hline & 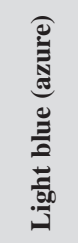 & 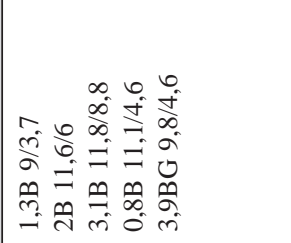 & & 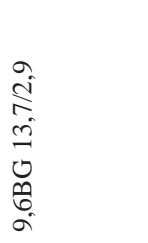 & $\begin{array}{l}\sigma \\
\rho^{2} \\
\sigma^{-} \\
0 \\
0 \\
0 \\
\infty\end{array}$ & 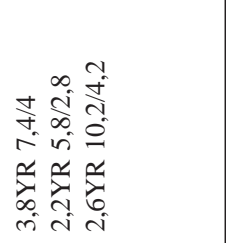 & 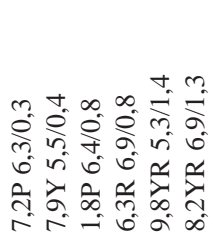 \\
\hline .气 & 芯 & 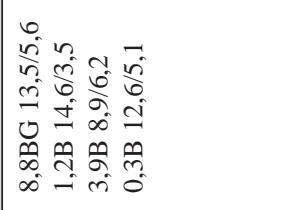 & 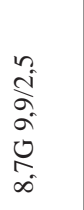 & 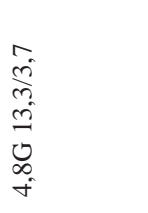 & & 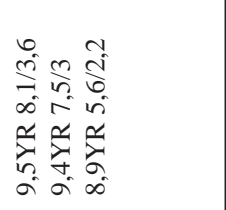 & 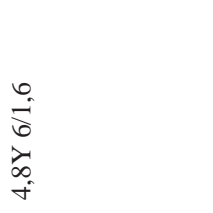 \\
\hline 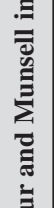 & שֶّ & 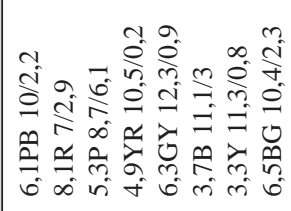 & 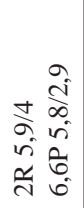 & 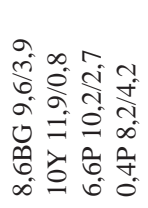 & 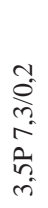 & 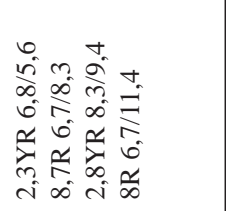 & 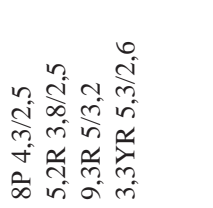 \\
\hline & 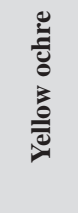 & 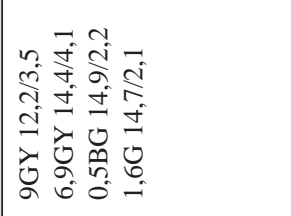 & 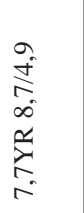 & 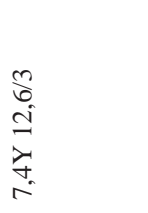 & 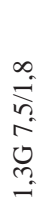 & 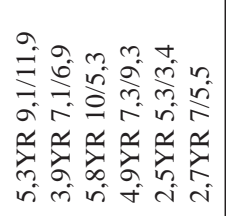 & 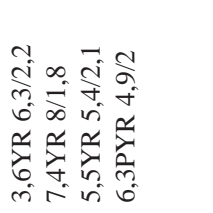 \\
\hline & 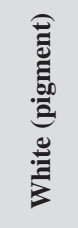 & & & & & 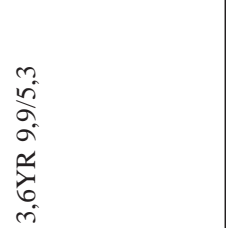 & 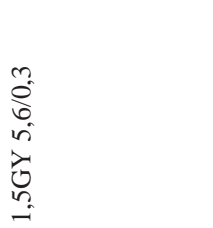 \\
\hline & 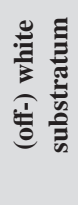 & 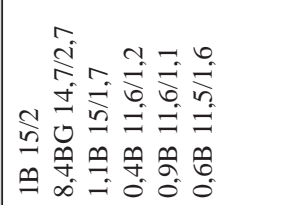 & 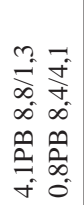 & 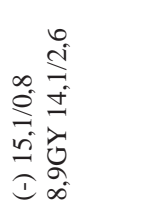 & 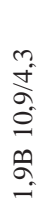 & 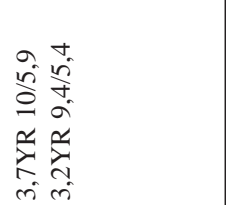 & 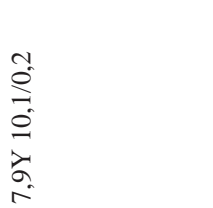 \\
\hline & $\begin{array}{l}\text { [ए!.ృ } \\
\text { UоL }\end{array}$ & $\vec{H}$ & $\stackrel{M}{\mapsto}$ & $\stackrel{ナ}{\oplus}$ & $\stackrel{\text { Lִ }}{\leftrightarrow}$ & $\hat{H}$ & $\stackrel{\overbrace{}}{H}$ \\
\hline
\end{tabular}




\begin{tabular}{|c|c|c|c|c|c|c|c|c|c|c|}
\hline 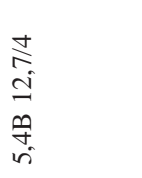 & $\begin{array}{l}\frac{\omega}{N} \\
m \\
\stackrel{n}{\omega} \\
\omega^{n}\end{array}$ & & 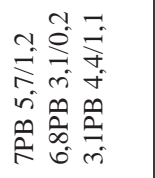 & & & 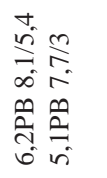 & 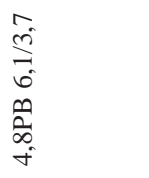 & 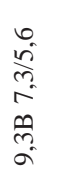 & 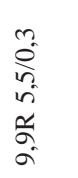 & 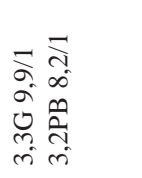 \\
\hline 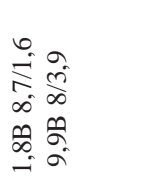 & & 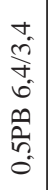 & 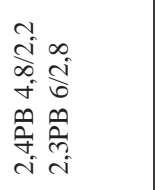 & \begin{tabular}{l}
$m$ \\
\multirow{1}{n}{} \\
$\cdots$ \\
$\infty$ \\
$\infty$ \\
$\infty$ \\
$\infty$
\end{tabular} & & $\begin{array}{l}\stackrel{+}{N} \\
\stackrel{N}{m} \\
\infty \\
\text { I }\end{array}$ & 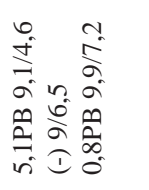 & & 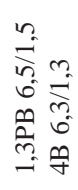 & 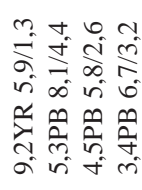 \\
\hline 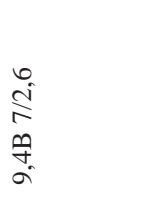 & & 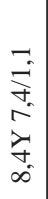 & 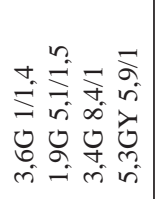 & & 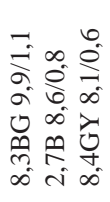 & 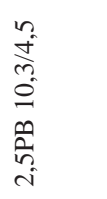 & 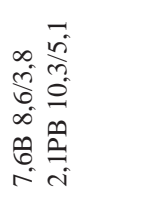 & $\begin{array}{l}m \\
\text { w } \\
\text { के } \\
m \\
\text { के } \\
\text { மึ }\end{array}$ & $\begin{array}{l}\infty \\
0^{-} \\
0^{-} \\
0 \\
0 \\
\infty \\
\infty\end{array}$ & 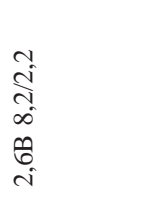 \\
\hline 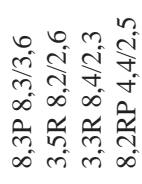 & 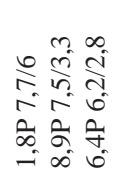 & 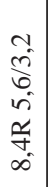 & 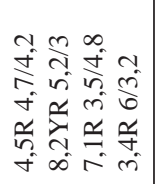 & 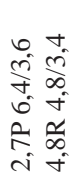 & 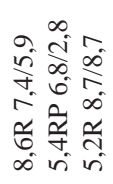 & 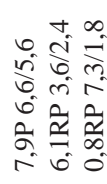 & 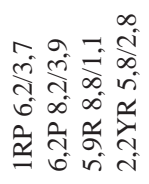 & 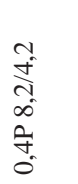 & 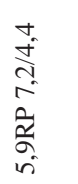 & 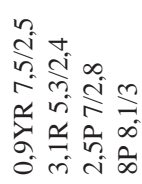 \\
\hline 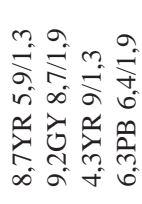 & $\begin{array}{l}1 \\
0 \\
0 \\
0 \\
0 \\
0 \\
\infty \\
0 \\
+\end{array}$ & 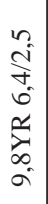 & 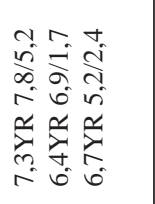 & 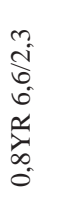 & 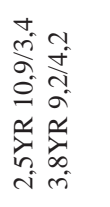 & 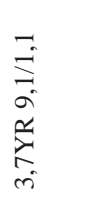 & 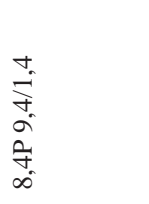 & 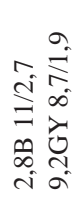 & 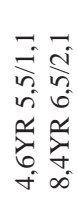 & 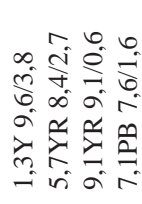 \\
\hline 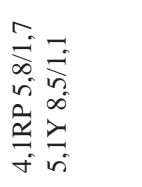 & & & 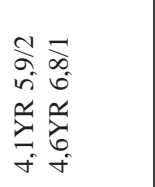 & & & & & & & 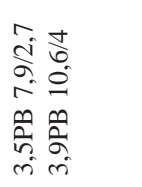 \\
\hline & $\stackrel{\Xi}{=}$ & & 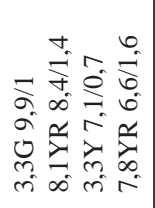 & $\begin{array}{l}\text { in } \\
\text { N } \\
\text { लि }\end{array}$ & 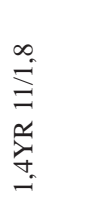 & 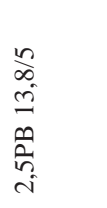 & 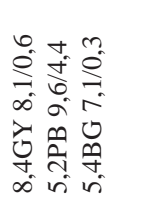 & 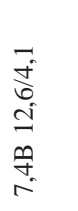 & 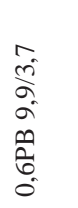 & 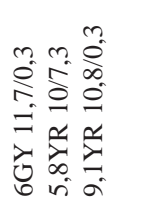 \\
\hline$\stackrel{ }{\stackrel{\leftrightarrow}{\leftrightarrow}}$ & $\stackrel{\sim}{\sim}$ & $\begin{array}{c}0 \\
\stackrel{1}{H}\end{array}$ & $\vec{H}$ & $\underset{\oplus}{\stackrel{\overbrace{}}{\oplus}}$ & $\underset{H}{\stackrel{\vec{H}}{H}}$ & $\underset{H}{\stackrel{N}{H}}$ & $\stackrel{\stackrel{N}{N}}{\leftrightarrow}$ & $\underset{H}{\stackrel{ \pm}{\sim}}$ & $\underset{\sim}{\stackrel{\nu}{N}}$ & $\stackrel{\widehat{N}}{\mapsto}$ \\
\hline
\end{tabular}




\section{APPENDIX II: PIGMENTS AND MORTARS}

The appendix lists part of the cards prepared for each sample, ${ }^{1}$ with the necessary information and a detailed presentation. For the discussion of the results of the samples' analyses refer to the main text of the article. For each of the tombs from which samples have been examined, the cards include some general details regarding the tomb and its wall paintings (i.e. state of preservation, climatic/environmental conditions) and related macroscopic observations. These follow the numbered samples from every tomb. These cards include: (a) a general description and a macroscopic photograph of the painted surface, (b) the results of the stereoscopic observation, and (c) the results of the mineralogical analysis shown in the X-ray diffractogram. In this way, a database is created, which in combination with the colour documentation database given above, can be a useful tool for future research. Hereunder, only a selection of samples is presented. Table 5 gives a summary of the quantitative (\% by weight) and mineralogical composition of all samples examined, using the X-ray diffraction method. Table 6 shows the most common colours and the pertinent minerals from which the colours derive, based on the pigments' identification.
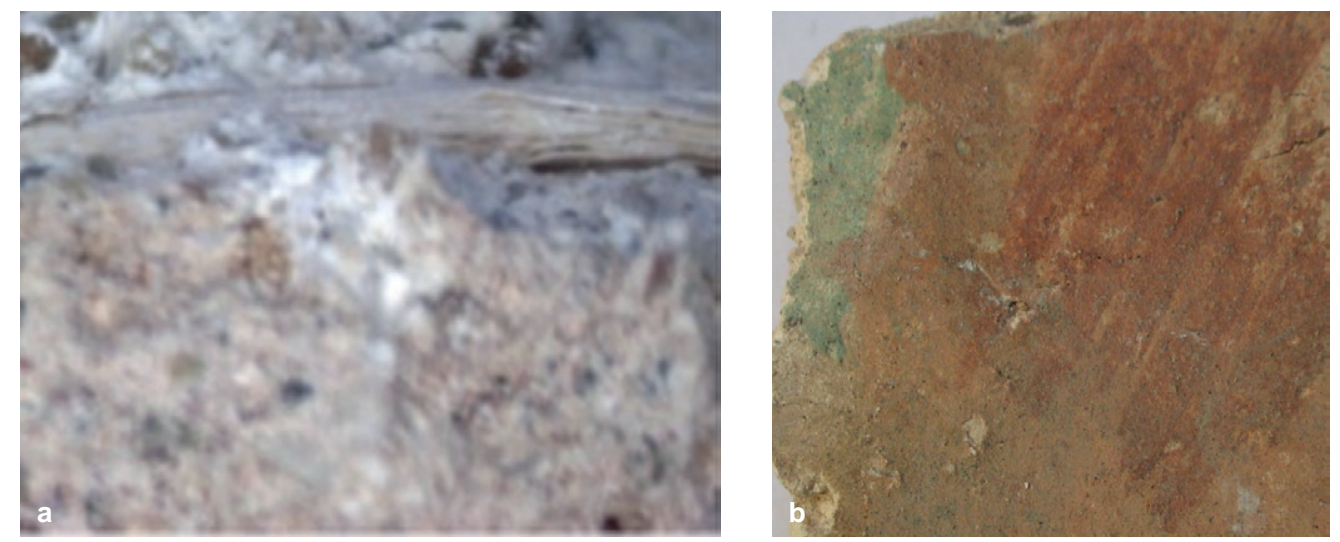

8. Samples from T.27: a. sample 30: fibres in the substratum, detected after stereoscopic observation; b. sample 22: lines from the painter's brush are discerned (Phot. V. Lysandrou).

${ }^{1}$ In total, thirty-one samples have been studied, coming from three tombs (samples 1-10 from T.9, samples 11-20 from T.7, samples 21-31 from T.27). Here we present only a small, indicative number, while the overall remarks and discussion in the main text, are based upon the entire corpus of the analyses. The full repository can be found in: Lysandrou 2014: 392-483. 
T.9 - SAMPLE 1

GENERAL DESCRIPTION
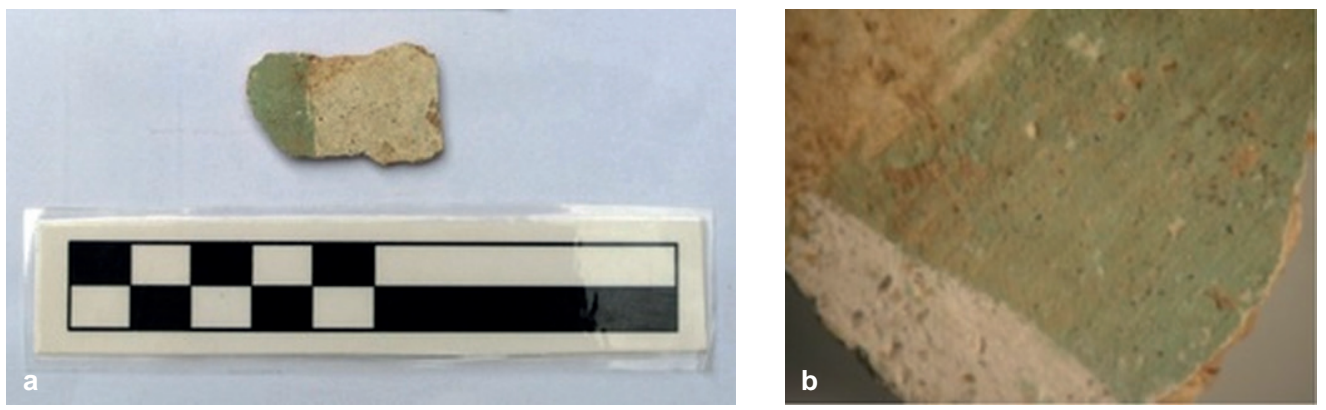

9. Sample 1 from T.9: a. macroscopic photograph of the sample’s painted surface; b. area of the pigment sampling (Phot. V. Lysandrou).

Original position of the sample (i.e. walls, roof of the chamber): unknown.

Description of the sample: painted fragment of irregular shape, approximately $3.3 \times 1.9 \times 0.3 \mathrm{~cm}$, with a thin layer of mortar (substrate). The colours that can be seen macroscopically on the surface of the sample are green and white. The sample was taken from the green area of the fragment.

Type of mortar (construction, filling, bonding, coating, etc.): coating.

Munsell Chart Colour Characterisation: 4,8Y 6/1,6. 

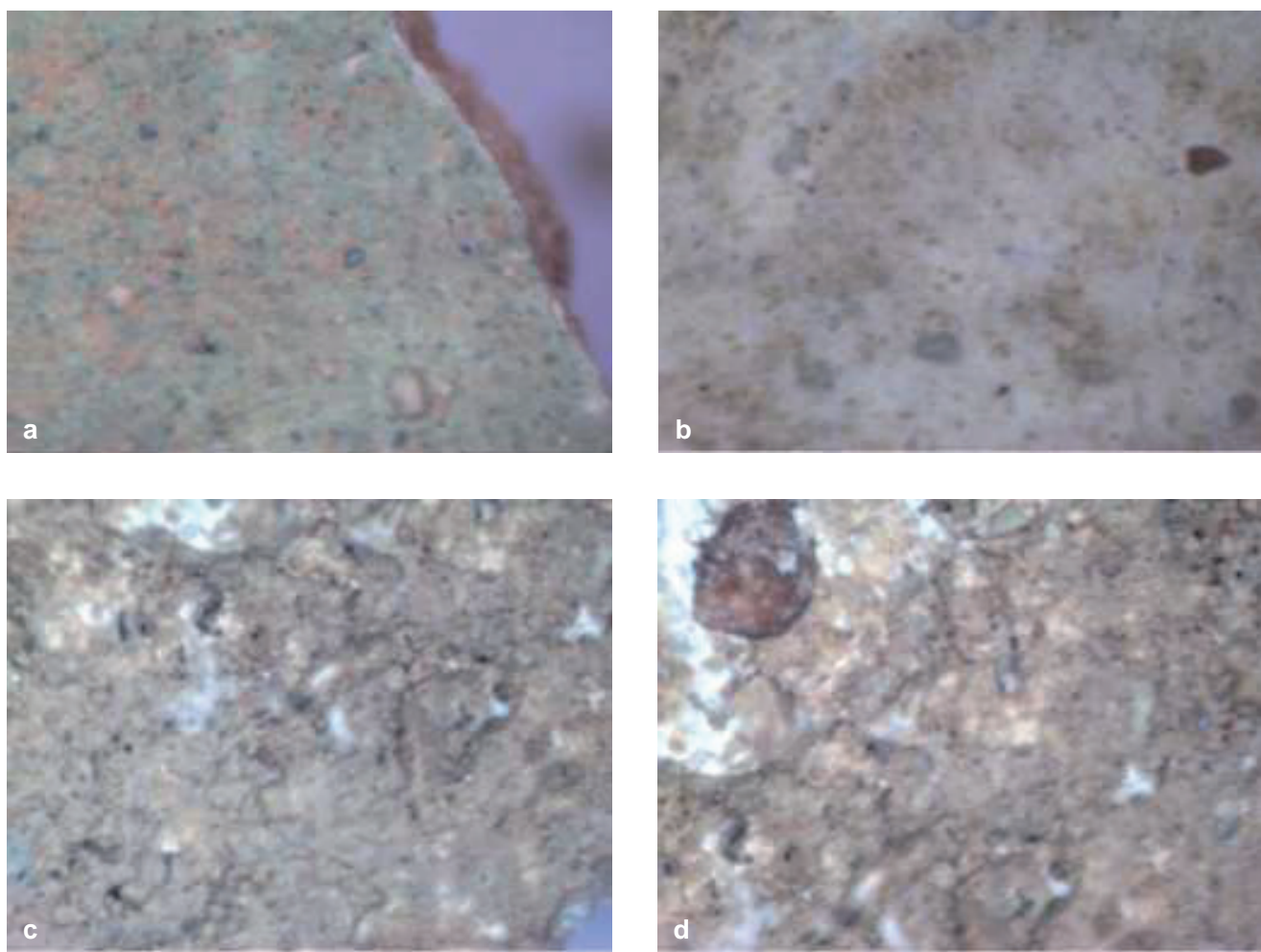

10. Microscopic observation of sample 1 from T.9: a. painted layer - green; b. painted layer - white; c-d. substrate mortar (Phot. V. Lysandrou).

Remarks: The green pigment is in a fairly good state of preservation. For the white background, white mortar was used. Small-medium size rounded aggregates and residues of the supporting body (natural bedrock, probably from the wall) are visible in the mortar. 


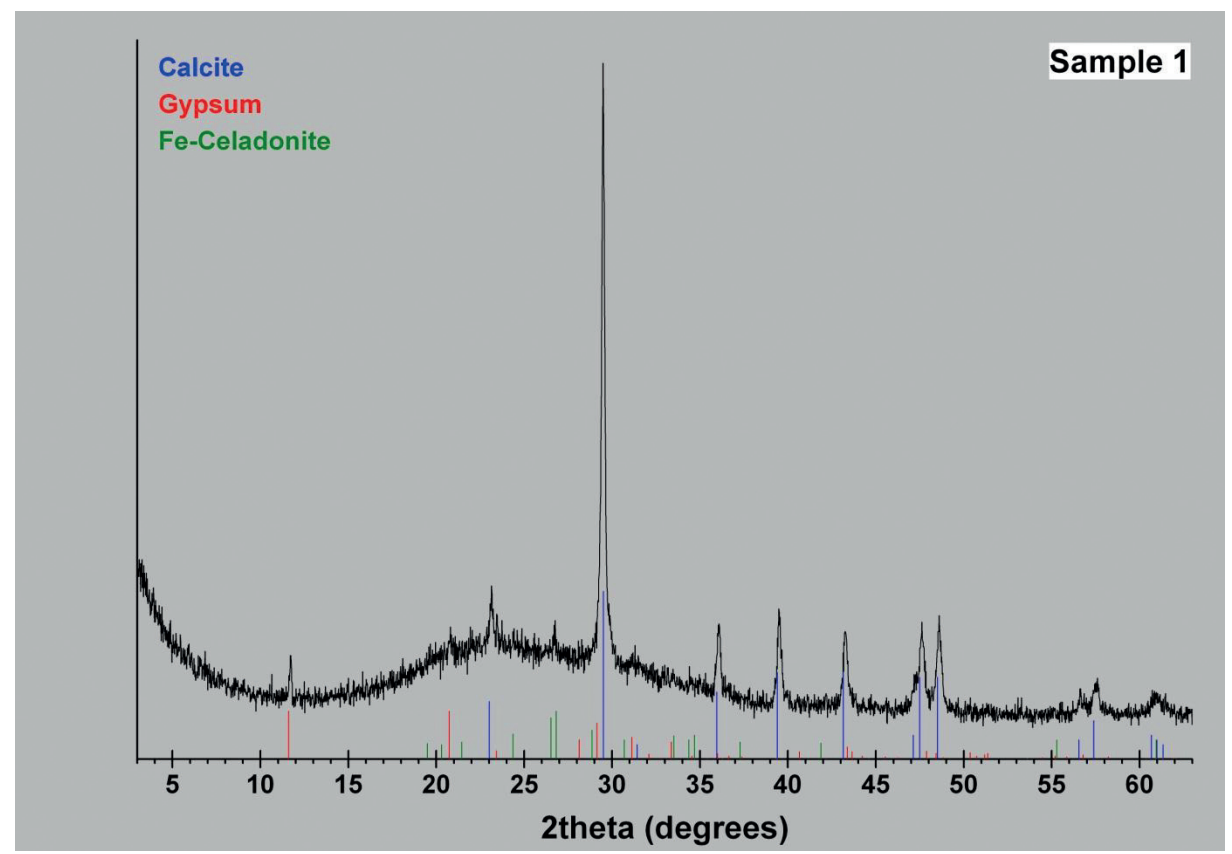

11. X-ray diffractogram of sample 1 from T.9.

Remarks: Macroscopically the colour of the pigment of sample 1 is characterised as green. Through X-ray diffractometry the following were identified: calcite (82\% by weight), gypsum (14\% by weight) and ferrous celadonite ( $4 \%$ by weight). The pigment is green ferrous celadonite, a key component of green earth. Calcite and possibly gypsum are components of the coating of the tested sample. 
T.9 - SAMPLE 3

GENERAL DESCRIPTION
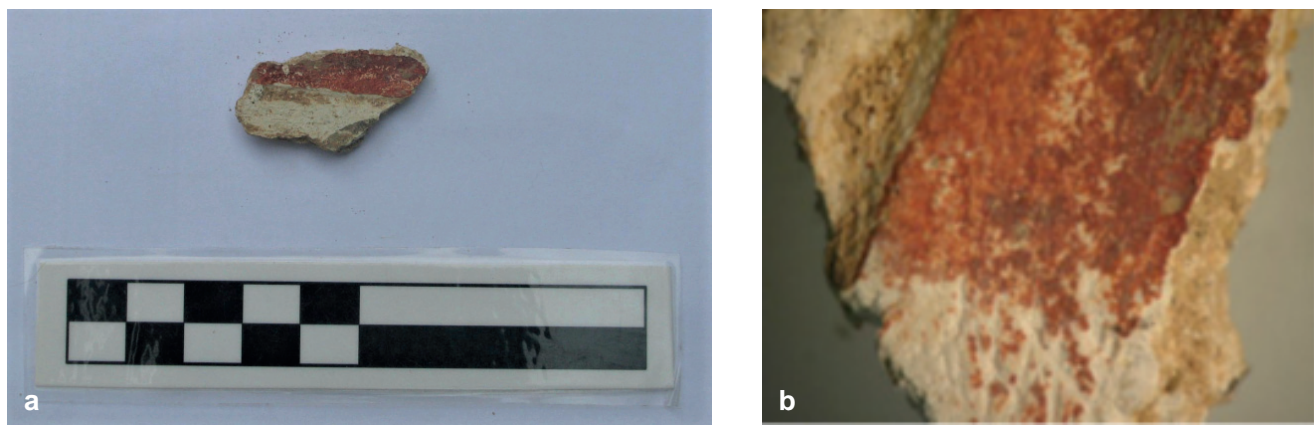

12. Sample 3 from T.9: a. macroscopic photograph of the sample's painted surface; b. area of the pigment sampling (Phot. V. Lysandrou).

Original position of the sample (i.e. walls, roof of the chamber): unknown.

Description of the sample: painted fragment of irregular shape, approximately $3.4 \times 1.8 \times 0.7 \mathrm{~cm}$, with a thin layer of mortar (substrate). The colours that can be seen macroscopically on the surface of the sample are red, white and black. The sample was taken from the red area of the fragment. The deep incision in the middle of the sample and at the point where the colour of the painted surface changes, defines a zone.

Type of mortar (construction, filling, bonding, coating, etc.): coating.

Munsell Chart Colour Characterisation: 8R 4,3/2,5

\section{MICROSCOPIC OBSERVATION}
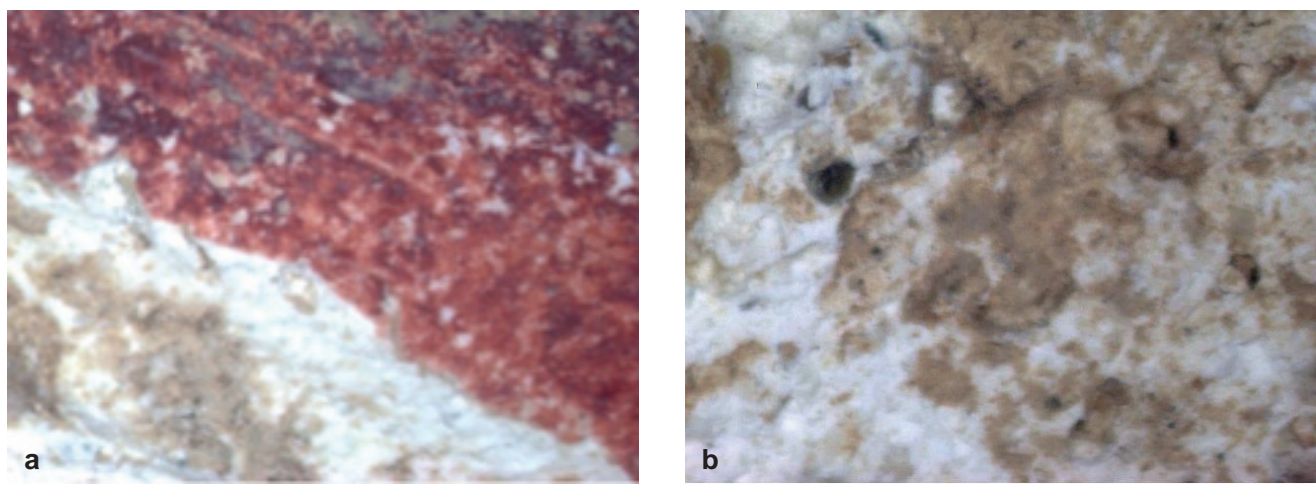

13. Microscopic observation of sample 3 from T.9: a. painted layer - red; b. mortar substrate (Phot. V. Lysandrou).

Remarks: There is a slight discolouration of the red pigment and detachments of the same pigment from specific spots. Parallel lines seen on the red colour are probably due to the painter's brush. Voids due to aggregate detachment can be seen in the stereoscopic photography of the substrate. 


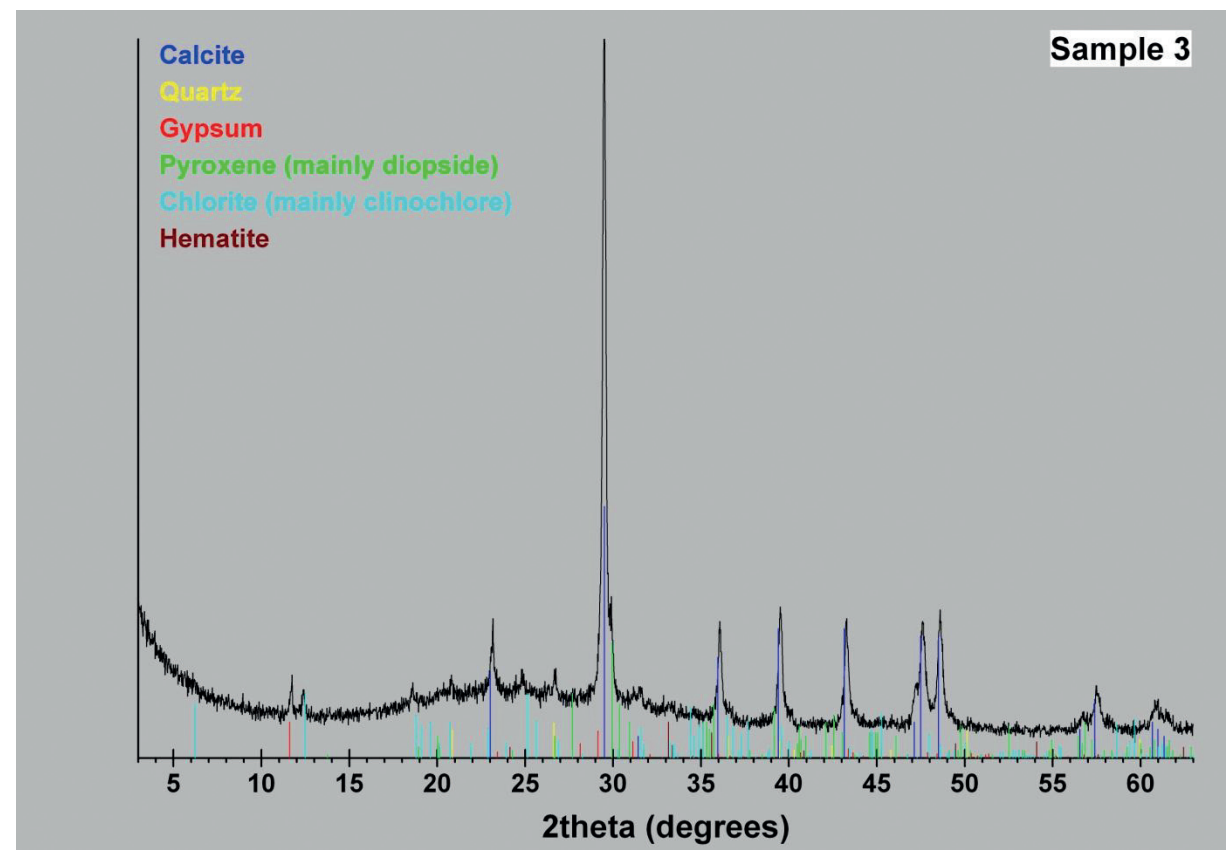

14. X-ray diffractogram of sample 3 from T.9.

Remarks: Macroscopically the colour of the pigment of sample 3 is characterised as red. Through X-ray diffractometry the following were identified: calcite (75\% by weight), gypsum ( $9 \%$ by weight), pyroxene ( $6 \%$ by weight, mainly diopside), chlorite ( $6 \%$ by weight, mainly bedrock), hematite ( $2 \%$ by weight) and quartz ( $2 \%$ by weight). The red colour of the sample comes from hematite, a mineral widely used as a pigment from antiquity to the present day because it gives a characteristic red hue. Calcite and possibly gypsum are components of the coating of the tested sample, while pyroxene, chlorite and quartz are possible components of the mortar. 
T.7 - SAMPLE 15

\section{GENERAL DESCRIPTION}
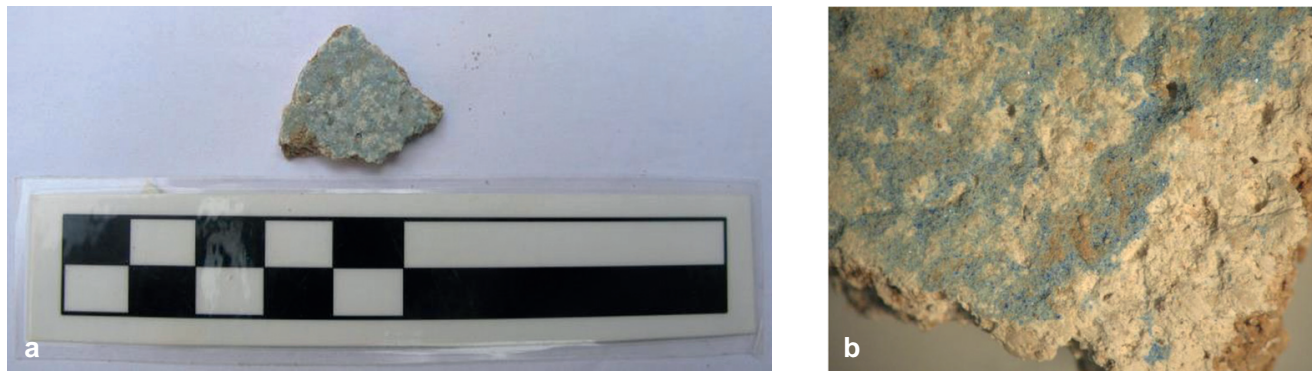

15. Sample 15 from T.7: a. macroscopic photograph of the sample's painted surface; b. area of the pigment sampling (Phot. V. Lysandrou).

Original position of the sample (i.e. walls, roof of the chamber): unknown.

Description of the sample: painted fragment of irregular shape, approximately $2.1 \times 2 \times 0.4 \mathrm{~cm}$, with a thin layer of mortar (substrate). Light blue colour can be seen macroscopically on the surface of the sample.

Type of mortar (construction, filling, bonding, coating, etc.): coating.

\section{MICROSCOPIC OBSERVATION}
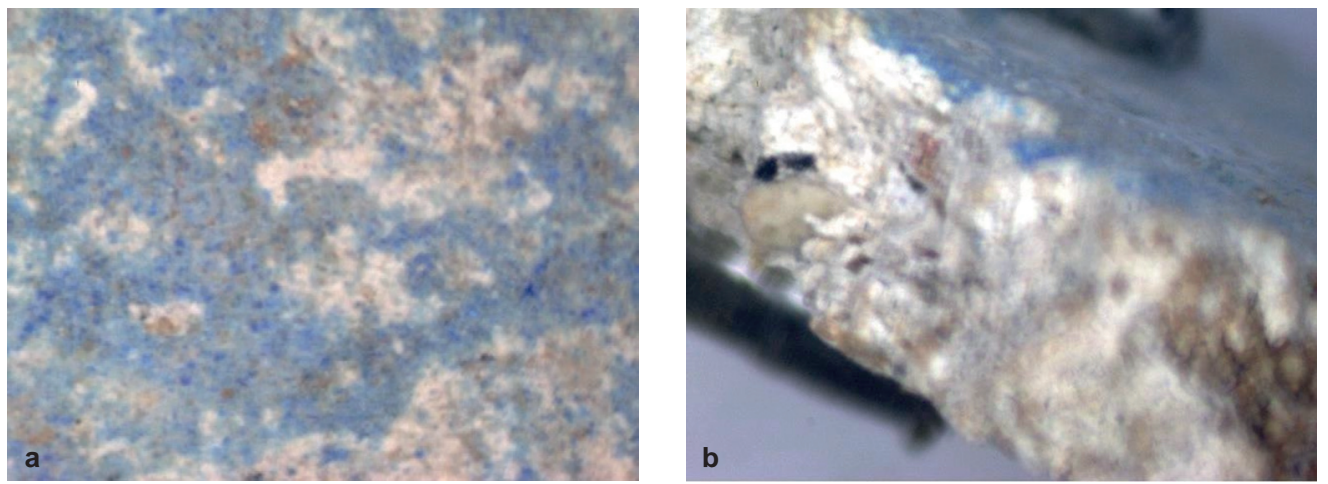

16. Microscopic observation of sample 15 from T.7: a. painted layer - light blue; b. layering (Phot. V. Lysandrou).

Remarks: Traces of carbon are visible, which could be residues from the lime processing. Detachment of the pigment is observed, perhaps due to disorganisation of the binder(?). Cracks and gaps are visible. 


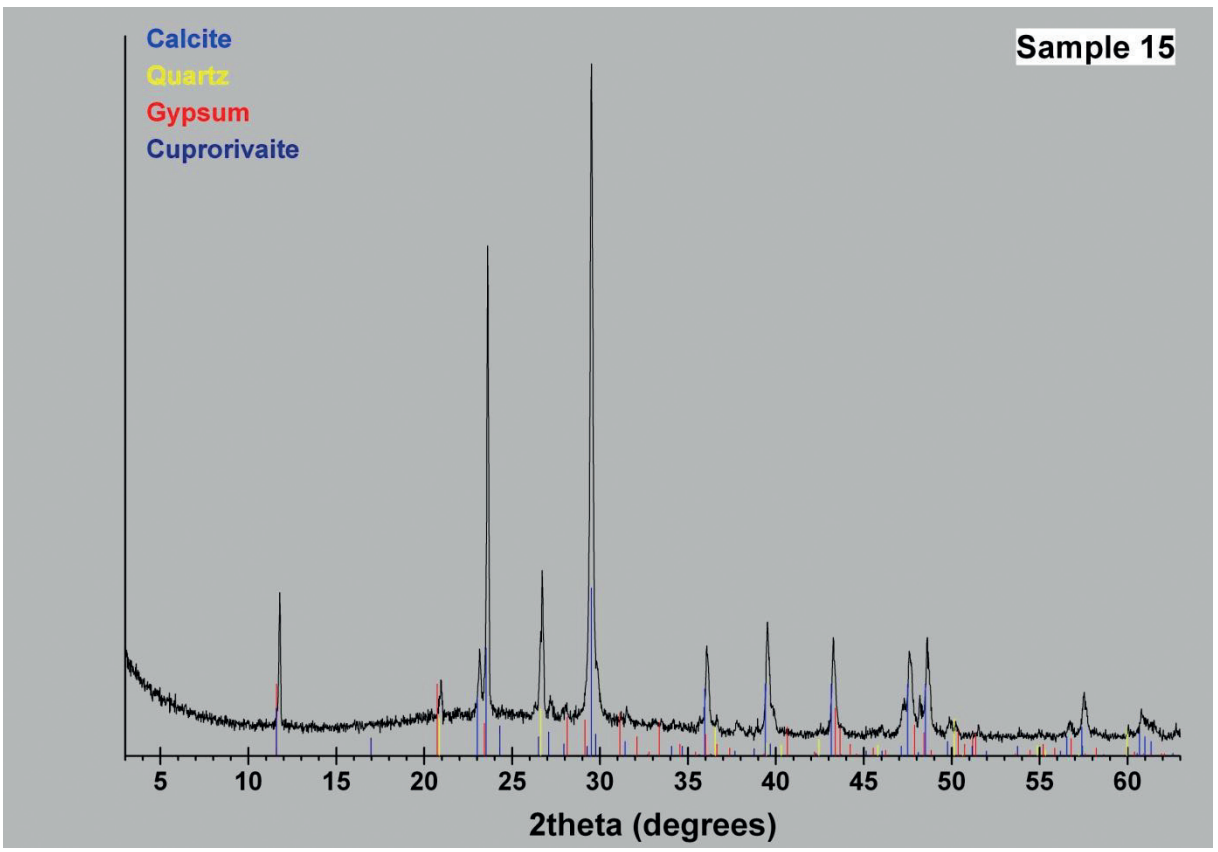

17. X-ray diffractogram of sample 15 from T.7.

Remarks: Macroscopically the colour of the pigment of sample 15 is characterised as light blue. Through X-ray diffractometry the following were identified: calcite (60\% by weight), gypsum (30\% by weight), quartz ( $7 \%$ by weight) and cuprorivaite (3\%). The mineral $\left(\mathrm{CaCu}+2 \mathrm{Si}_{4} \mathrm{O}_{10}\right)$ is known as Egyptian blue and is the identified pigment. Calcite and possibly gypsum are components of the coating of the sample, while quartz is probably a component of the mortar. 
T.27 - SAMPLE 29

\section{GENERAL DESCRIPTION}
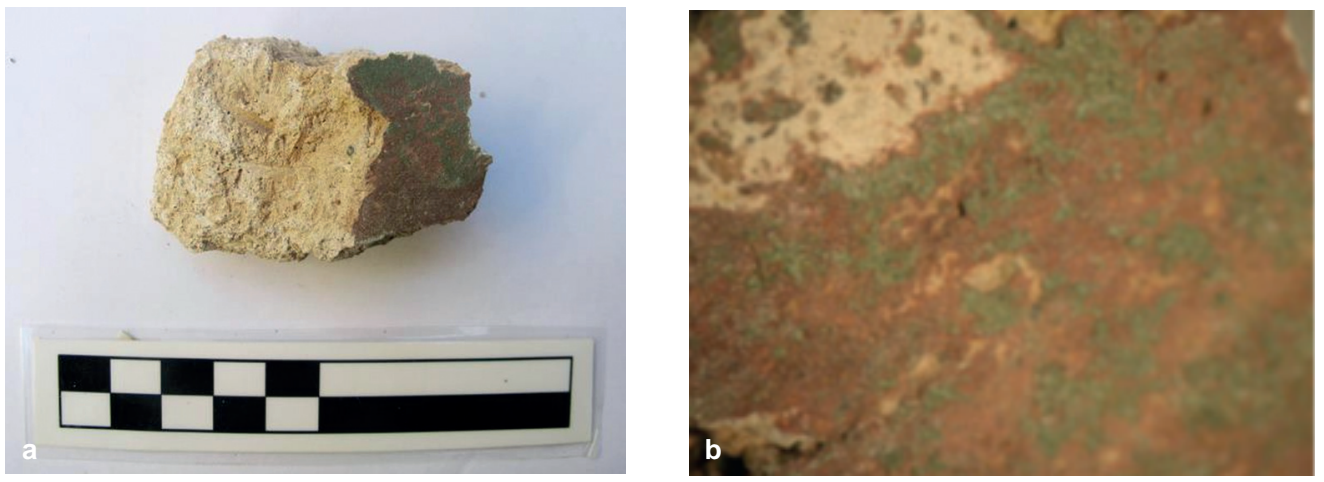

18. Sample 29 from T.27: a. macroscopic photograph of the sample’s painted surface; b. area of the pigment sampling (Phot. V. Lysandrou).

Original position of the sample (i.e. walls, roof of the chamber): unknown.

Description of the sample: painted fragment of irregular shape, approximately $5.5 \times 3.8 \times 3.7 \mathrm{~cm}$, with a thin layer of mortar (substrate). The colours that can be seen macroscopically on the surface of the sample are deep red and green. A sample was taken for each colour. Type of mortar (construction, filling, bonding, coating, etc.): coating. 


\section{MICROSCOPIC OBSERVATION}
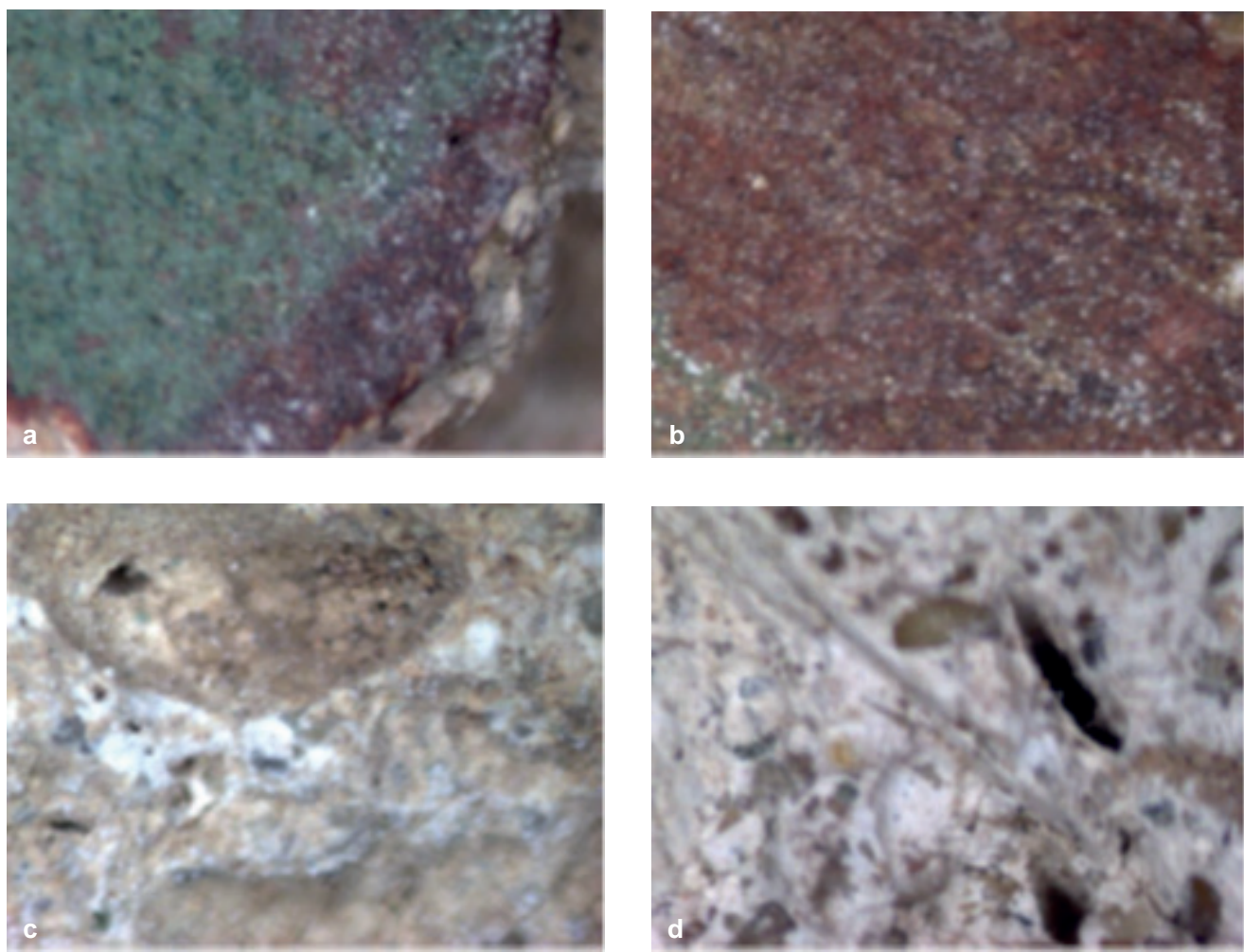

19. Microscopic observation of sample 29 from T.27: a-b. overpainted layers; c-d. substratum mortar (Phot. V. Lysandrou).

Remarks: An imprint of lost organic material, possibly fibre, can be seen. The substrate contains carbon, while the voids and inclusions are rather due to aggregate detachment. 
Table 5. The summary of the quantitative (\% by weight) and mineralogical composition of all samples examined, using the X-ray diffraction method; C: Calcite; G: Gypsum; Q: Quartz; Px: Pyroxenes (mainly diopside); A: Amphiboles; Mic: Mica; Ch: Chlorite (mainly clinochlore); Do: Dolomite; Pl: Plagioclase; Kf: K-rich feldspars; An: Analcime; Ht: Hematite; Mt: Magnetite; Go: Goethite (component of ochre); FeC: Ferrous celadonite; (green earth); Cup: Cuprorivaite (Egyptian blue); Ha+Ve: Hausmannite and Vernadite (components of brown-black Umber)

\begin{tabular}{|c|c|c|c|c|c|c|c|c|c|c|c|c|c|c|c|c|c|}
\hline \multirow{2}{*}{ 总 } & \multicolumn{17}{|c|}{ Mineral and percentage of mineral composition } \\
\hline & $\cup$ & 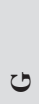 & $\sigma$ & $\stackrel{x}{a}$ & $\varangle$ & $\dot{U}$ & $\tilde{v}$ & ค̊ & $\bar{a}$ & \pm & 娄 & 击 & $\bar{\Sigma}$ & ن & U. & 气े & 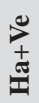 \\
\hline 1 & 82 & 14 & & & & & & & & & & & & & 4 & & \\
\hline 2 & 98 & & 2 & & & & & & & & & & & & & & \\
\hline 3 & 75 & 9 & 2 & 6 & & & 6 & & & & & 2 & & & & & \\
\hline 4 & 94 & 4 & 1 & & & & & & & & & 1 & & & & & \\
\hline 5 & 55 & 40 & & & & & & & & & & & & & 5 & & \\
\hline 6 & 30 & 65 & & & & & & & & & & & & & 3 & & 2 \\
\hline 7 & 81 & 15 & 1 & & & & & & & & & & & 3 & & & \\
\hline 8 & 82 & 13 & 2 & & & & & & & & & 1 & & 2 & & & \\
\hline 9 & 22 & 75 & 1 & 2 & & & & & & & & & & & & & \\
\hline 10 & 100 & & & & & & & & & & & & & & & & \\
\hline 11 & 94 & & & & & & & & & & & & & 4 & 2 & & \\
\hline 12 & 98 & & & & & & & & & & & & & & 2 & & \\
\hline $13 b$ & 91 & & 3 & 4 & & & & 1 & & & & & 1 & & & & \\
\hline 13bl & 64 & 24 & 9 & & & & & & & & & & & & & 3 & \\
\hline 14 & 17 & 78 & 2 & & & & & & & & & 3 & & & & & \\
\hline 15 & 60 & 30 & 7 & & & & & & & & & & & & & 3 & \\
\hline $16 r$ & 96 & & 1 & & 1 & & & & & & & 2 & & & & & \\
\hline $16 y$ & 97 & & & & & & & & & & & & & 3 & & & \\
\hline 17 & 96 & & 2 & & & & & & & & & & & 2 & & & \\
\hline 18 & 92 & & 3 & 4 & & & & & & 1 & & & & & & & \\
\hline 19 & 8 & 90 & & & & & & & & & & & & & & 2 & \\
\hline 20 & 7 & 91 & 1 & & & & & & 1 & & & & & & & & \\
\hline $21 b$ & 62 & 35 & 3 & & & & & & & & & & & & & & \\
\hline $21 r$ & 44 & 43 & 5 & 5 & & & & & & & & 3 & & & & & \\
\hline 22 & 97 & & 2 & & & & & & & & & 1 & & & & & \\
\hline 23 & 84 & 4 & 2 & & & & & & 1 & & 5 & & & & & & \\
\hline
\end{tabular}




\begin{tabular}{|c|c|c|c|c|c|c|c|c|c|c|c|c|c|c|c|c|c|}
\hline \multirow{2}{*}{ 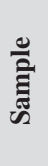 } & \multicolumn{17}{|c|}{ Mineral and percentage of mineral composition } \\
\hline & $u$ & ט & $\sigma$ & $a$ & $\varangle$ & $\sum$ & U & $\stackrel{\circ}{\circ}$ & $\bar{\alpha}$ & $\underline{z}$ & $\varepsilon$ & 击 & $\sum$ & 广 & U. & जे & 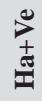 \\
\hline 24 & 78 & & 2 & 16 & & 1 & & & & & & 3 & & & & & \\
\hline 25 & 74 & & 2 & 17 & & & & & & & & 3 & & & 4 & & \\
\hline 26 & 96 & & 2 & & & & & & & & & & & 2 & & & \\
\hline 27 & 89 & & 4 & 5 & & & & & & & & & & 2 & & & \\
\hline 28 & 58 & 27 & 4 & 8 & & & & & & & & 3 & & & & & \\
\hline 29 & 94 & & & & & & & & & & & & & & 6 & & \\
\hline 30 & 68 & 29 & 2 & & & & & & & & & & & & & 1 & \\
\hline 31 & 63 & 5 & 2 & 25 & & & & & & & & & & & 5 & & \\
\hline
\end{tabular}

Table 6. Most common colours and the pertinent minerals from which the colours derive, based on the pigments' identification

\begin{tabular}{|c|l|l|l|c|l|l|}
\hline \multirow{2}{*}{$\begin{array}{c}\text { Tomb } \\
\text { serial } \\
\text { no. }\end{array}$} & \multicolumn{6}{|c|}{ Colour } \\
\cline { 2 - 7 } & \multicolumn{7}{|c|}{ White } & \multicolumn{1}{|c|}{ Red } & \multicolumn{1}{|c|}{ Yellow } & \multicolumn{1}{c|}{ Green } & \multicolumn{1}{c|}{ Black } & Blue \\
\hline T.7 & Calcite & Hematite & Goethite & Green Earth & Magnetite & Egyptian blue \\
\hline T.9 & Calcite & Hematite & Goethite & Green Earth & Black umber & - \\
\hline T.27 & Calcite & Hematite & Goethite & Green Earth & Amorphous carbon & Egyptian blue \\
\hline
\end{tabular}




\section{ÉTUDES et TRAVAUX XXXIV / 2021}
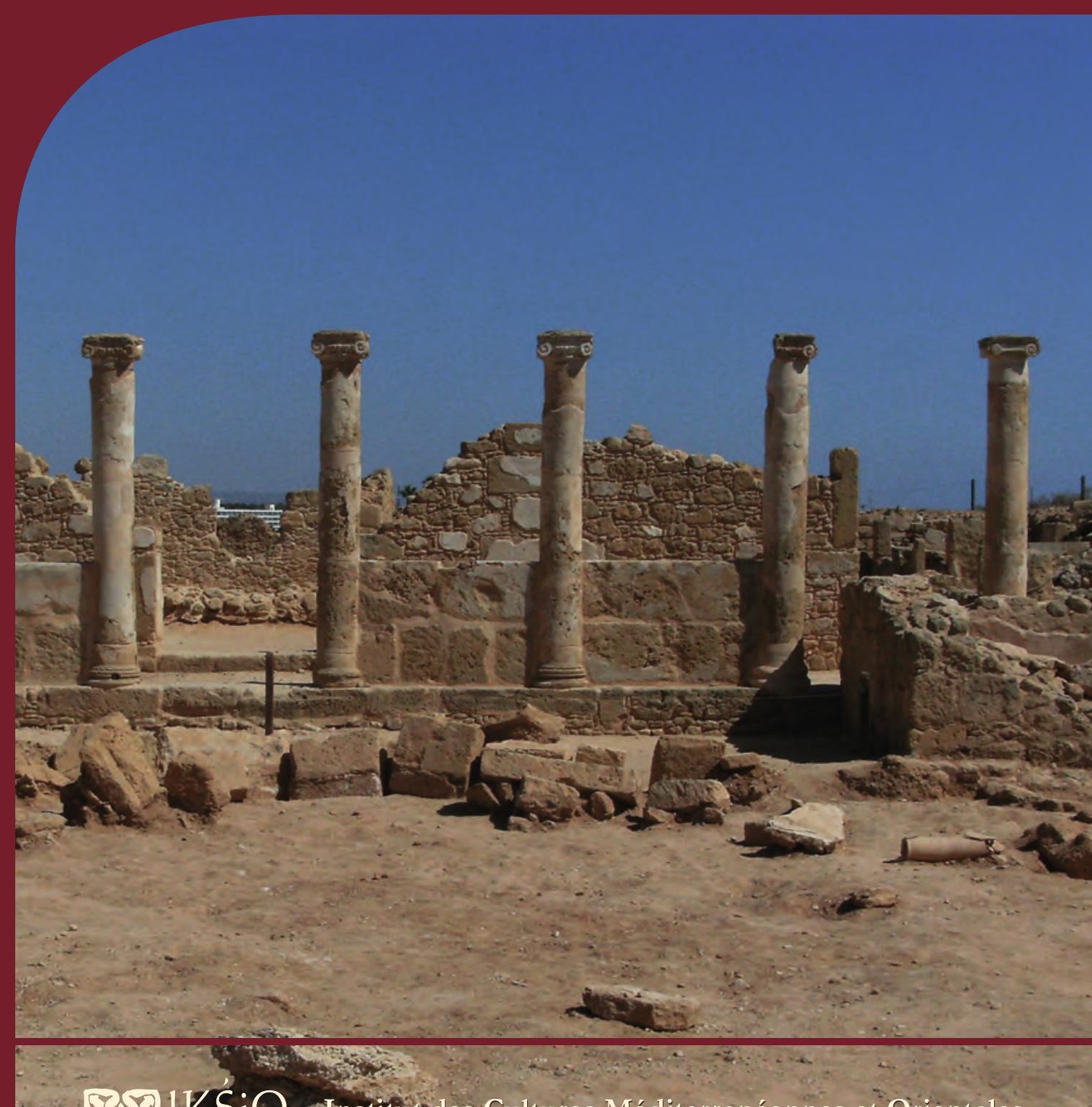

W $92 \mathrm{HKSiO}$ Institut des Cultures Méditerranéennes et Orientales

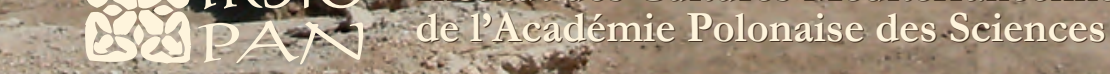

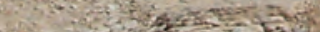

Q 
COMITÉ DE RÉDACTION SCIENTIFIQUE

Maciej Makowski - rédacteur en chef

Jadwiga Iwaszczuk - rédacteur

Katarzyna Kapiec - secrétaire de la rédaction

Henryk Meyza - rédacteur thématique du volume

CONSEIL SCIENTIFIQUE DU JOURNAL

M. Kobusiewicz (IAE PAN, Warszawa)

E. Laskowska-Kusztal (IMOC PAS, Warszawa)

D. Michaelides (University of Cyprus, Nicosia)

J.Ch. Moretti (IRAA-MOM, Université de Lyon 2/CNRS)

D. Raue (Ägyptisches Museum der Universität Leipzig)

P. Reynolds (ICREA, España)

D. Welsby (British Museum, London)

COMITÉ SCIENTIFIQUE DE LECTURE

la liste des membres du comité est accessible en ligne sur

http://www.etudesettravaux.iksiopan.pl

RÉDACTION TECHNIQUE

Marta Kaczanowicz

REVUE DES TEXTES EN ANGLAIS

Jo Harper 
ÉTUDES et TRAVAUX XXXIV 
INSTYTUT KULTUR ŚRÓDZIEMNOMORSKICH I ORIENTALNYCH POLSKIEJ AKADEMII NAUK

\title{
STUDIA i PRACE
}

\section{XXXIV}

\author{
GoIKSiO \\ QSO PAN \\ WARSZAWA \\ 2021
}


INSTITUT DES CULTURES MÉDITERRANÉENNES ET ORIENTALES DE L’ACADÉMIE POLONAISE DES SCIENCES

\section{ÉTUDES et TRAVAUX}

XXXIV

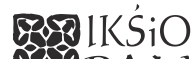

EOSPAN

VARSOVIE

2021 
Publication scientifique financée dans le cadre du programme du Ministre de la Science et de l’Éducation Supérieure

« Programme National de Développement de l’Humanistique » pour les années 2016-2021 (projet no 3bH 150099 83)

\title{
(1) NARODOWY PROGRAM ROZWOJU HUMANISTYKI
}

\author{
Copyright $(C)$ \\ Instytut Kultur Śródziemnomorskich i Orientalnych PAN \\ et les Auteurs \\ Warszawa 2021
}

ISSN 2084-6762

(jusqu'en 2011 : 0079-3566)

e-ISSN 2449-9579
Version première en papier, imprimée en Pologne - 150 copies
Version électronique accessible sur
http://www.etudesettravaux.iksiopan.pl

Édition: Polskie Towarzystwo Historyczne et Wydawnictwo Neriton, Warszawa

Conception générale de la couverture : J. Iwaszczuk

Photographie de couverture : Phot. A. Brzozowska-Jawornicka

(Le portique ionique est, péristyle de la Maison « hellénistique », Nea Paphos) 


\section{Table des matières}

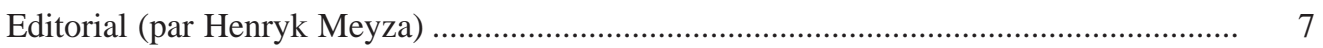

Marta BaJTLER

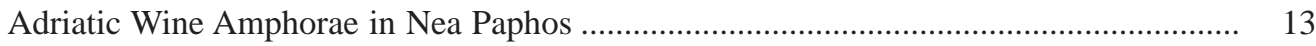

Claire Balandier, Jolanta MlynarczyK

The Temple and Its Surroundings on Fabrika Hill, Paphos: Preliminary Results

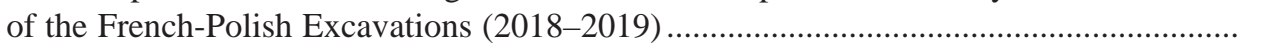

Grażyna BĄKowska-Czerner, Rafal CzERner

The Shell Motif in the Culture and Architecture of the Ancient Town of Marina el-Alamein in Egyp

AleKsandra BrzozowsKa-JaWornicKa

'Hellenistic' House in Nea Paphos, Cyprus - A First Summary of Its Architecture.

AleKsandra BrzozowsKa-JaWORnicKA, AnNa KuBICKA-SowińsKa

In Search of the Module in the Architectural Design of the 'Hellenistic'

House in Nea Paphos, Cyprus

RoKsana HaJduga

Kushite Stamp Impressions from Selib 2, Sudan

ERSIN HusSEIN

Mapping Metal Rich Roman Cyprus: The Case for Object-Centred Approaches

BARBARA LICHOCKA

Villa of Theseus at Nea Paphos (Cyprus). Fourth-Early Fifth Century Numismatic

Evidence for Architectural Transformations and Seismic Events

VASiliki Lysandrou, Demetrios Michaelides

Wall Paintings in Ancient Cyprus: The Hellenistic and Roman Tombs of Paphos

and Its Region

ADAM ŁAJTAR

A Weight of Seleucia in Pieria in Nea Paphos

Diana MroczeK

Ancient Portrait Busts of Marcus Aurelius in the National Museum in Poznań 
Brandon R. Olson, R. Scott Moore, Thomas Landvatter, Justin Stephens

Pyla-Vigla: A Case Study Assessing the Imperial Strategies of the Hellenistic

Diadochoi in Cyprus

Patrizio Pensabene, Eleonora Gasparini

Colonnaded Hall in Kourion: How the Oecus Corinthius Was Interpreted in the Roman

Houses of Cyprus

Monika Rekowska, Demetrios Michaelides, Skevi Christodoulou, JAKUB KANISZEWSKI

Adopting Roman Habits - The Baths in the House of Orpheus in Nea Paphos

as a 'Troublesome' Case Study?

MARCIN M. ROMANIUK

Terracotta Pipelines at Maloutena: Remarks on the Water System in the

Residential District of Ancient Nea Paphos, Cyprus

363

ABRÉVIATIONS

407 